\title{
December 2017
}

Grass[and] research and conservatio

IAVS

\section{Bulletin 35}

\section{of the Eurasian Dry Grassland Group}

\section{Content \\ Editorial \\ The elections of the EDGG Executive Com- mittee 2017 \\ Governance of EDGG in the election period 2017-2019}

EGC 2018 First call

11th EDGG Field Workshop First call

Report from the 14th Eurasian Grassland Conference

EDGG General Assembly 2017

Short contributions

Recent publications of our members

Forthcoming events

\section{Dear members of the Eurasian Dry Grassland Group,}

We are grateful that in the elections this summer you gave us your vote to lead the EDGG during the next two years. Meanwhile the new Executive Committee has constituted itself and distributed its duties. To inform you who is responsible for what and whom you should contact for which question, we provide on the first pages of this Bulletin a slightly more detailed overview than in normal Bulletin issues.

This year, EDGG conducted a Field Workshop in Central Italy (detailed report to follow in the next Bulletin) and the Eurasian Grassland Conference (EGC) in Latvia and Lithuania (see report on pp. 11-19). This Bulletin also contains the first announcements of next year's EGC in Central Italy and of the Field Workshop in Austria. The whole is complemented by several smaller items.

We are looking forward to collaborating with you, our members, and wish you a pleasant festive season and a good start to the new year,

\section{Anna Kuzemko and Idoia Biurrun with Didem Ambarli, Jürgen} Dengler, Péter Török, Stephen Venn and Michael Vrahnakis

At the top:

Anthropogenic grasslands near Vinkove village, Mukacheve district, Transcarpathian region, Ukraine. Photo: 0 . Bezsmertna. 


\section{News}

\section{The elections of the EDGG Executive Committee 2017-2019}

A total of eight candidates stood in the 2017 election of the Executive Committee. The election was conducted from $18^{\text {th }}$ June until the $1^{\text {st }}$ July. The eight candidates were Didem Ambarlı (Turkey), Idoia Biurrun (Spain), Iwona Dembicz (Poland), Jürgen Dengler (Switzerland), Anna Kuzemko (Ukraine), Péter Török (Hungary), Stephen Venn (Finland/UK) and Michael Vrahnakis (Greece).

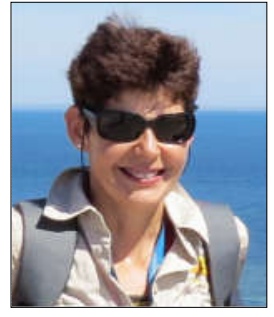

Idoia Biurrun

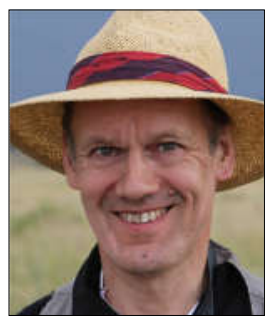

Stephen Venn

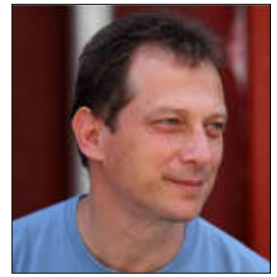

Michael Vrahnakis

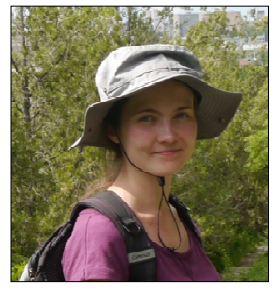

Iwona Dembicz

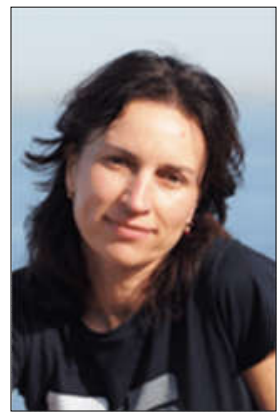

Monika Janišová

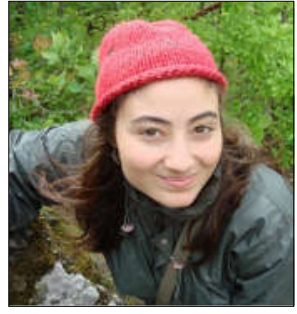

Didem Ambarlı

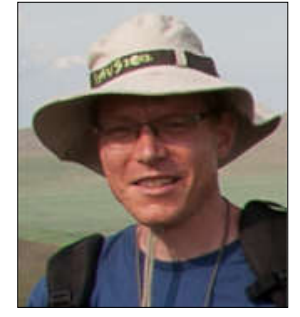

Jürgen Dengler

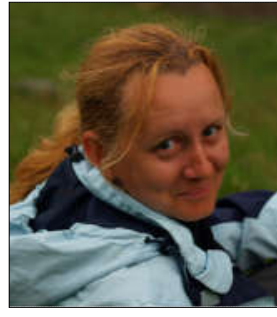

Anna Kuzemko

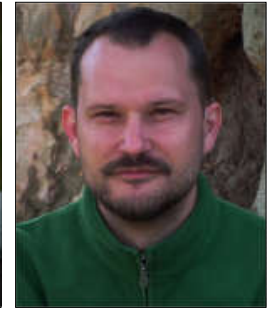

Péter Török
Table. Results of the election for the Executive Committee of the EDGG 2017.

Candidate

Votes

Percent Rank Elected

\begin{tabular}{lcccc}
\hline Idoia Biurrun & 95 & 14 & 1 & $\mathrm{x}$ \\
Anna Kuzemko & 90 & 13 & 2 & $\mathrm{x}$ \\
Jürgen Dengler & 88 & 13 & 3 & $\mathrm{x}$ \\
Péter Török & 88 & 13 & 3 & $\mathrm{x}$ \\
Stephen Venn & 80 & 12 & 4 & $\mathrm{x}$ \\
Michael Vrahnakis & 76 & 11 & 5 & $\mathrm{x}$ \\
Didem Ambarlı & 72 & 11 & 6 & $\mathrm{x}$ \\
Iwona Dembicz & 64 & 9 & 7 &
\end{tabular}

Our bylaw 4.2 states that: Election (a) The Executive Committee shall regularly consist of seven members, and ( $f$ ) Those seven candidates with the highest number of votes are elected. In the case of a tie for the seventh position, all candidates with the same number of votes are elected. In order to improve geographic representativeness, the one member based in Europe (in a physical-geographical sense) and the one based outside Europe with the highest number of votes shall be elected even if they are not among the seven with the overall highest number of votes. This means that the first seven candidates in the table above have been elected and unfortunately Iwona Dembicz was not. Thus the new EC comprises seven members, whose two year term of office will extend until the General Assembly in 2019. We thank you for your trust in us!

One of the founder members of the EDGG, Monika Janišová did not stand for the elections this time. We sincerely thank her for her many years of work as Founder and long term Editor-in-Chief of EDGG Bulletin and Representative to IAVS.
The aims of the EDGG are:

- to compile and distribute information on research and conservation of natural and semi-natural grasslands beyond national borders;

- to stimulate active cooperation among grassland scientists (exchanging data, common data standards, joint projects).

To achieve its aims, the EDGG provides seven instruments for the exchange of information among grassland researchers and conservationists:

- the Bulletin of the EDGG (published quarterly);

- the EDGG homepage (www.edgg.org);

- e-mails via our mailing list on urgent issues;

- the Eurasian Grassland Conference - organized annually at different locations throughout the Palaearctic Realm;

- EDGG research expeditions and field workshops to sample baseline data of underrepresented regions of the Palaearctic Realm;

- EDGG vegetation databases;

- Special Features on grassland-related topics in various peerreviewed journals. 


\section{Governance of EDGG}

\section{in the election period 2017-2019}

In its first joint phone conference (8.12.2017) after the election, the seven newly elected Executive Committee (EC) members of EDGG made several important decisions. They appointed one of their members for each of the six officer functions required according to EDGG Bylaws Article 4.4.a and several non-obligatory functions. According to Bylaws Article 7.3, the EC established a Special Committee (called: Editorial Board) for the EDGG Bulletin, consisting both of EC members and non-members. The EC also decided, with a three quarters majority, to dissolve the one topical and four regional subgroups because they have been inactive for a long period (Article 7.2).

We hereby inform you who will be responsible for what activities during the next two years.

\section{Secretary-General \\ Officer: Stephen Venn (stephen.venn@helsinki.fi)}

My principle responsibility is to take care of secretarial duties regarding the activities of the EC, such as organizing, hosting and documenting committee meetings and General Assemblies, in collaboration with the other members of the EC. I am also responsible for communicating with other organizations (except IAVS). This has included the issuing of statements on national policies that affect the conservation of grasslands.

You are welcome to use me as a contact point for the EDGG. If I am unable to help directly, I can put you in contact with the appropriate official.

\section{Membership Administrator \\ Officer: Idoia Biurrun (idoia.biurrun@ehu.es)}

I keep the membership database with data of all EDGG members up-to-date and maintain functioning mailing lists to be used in all batch mailing of EDGG: information of our activities with announcements of EGCs and FWs, publication of new issues of the Bulletin, etc. I am also in charge of advertising and inviting new members, and I provide membership statistics for the Bulletin, homepage and EDGG advertising material.

You should contact me whenever your affiliation and particularly your e-mail change. You are also welcome to communicate with me regarding any important issue that you would like to disseminate to the membership.

\section{IAVS Representative and Treasurer}

Officer: Péter Török (molinia@gmail.com)

Deputy Officer: Didem Ambarlı

(didem.ambarli@gmail.com)

We coordinate the communication of the EDGG EC with various subgroups, committees, the council and governing board of IAVS. We deal with financial issues of the working group and coordinate the financial and administrative duties for EDGG - run projects, supported by the IAVS (individual projects, fellowships, and travel grants). We prepare yearly reports for the IAVS council and financial reports of the working group for the General Assembly and EDGG EC.

You can contact us if you would like to know more about various benefits of becoming a member of the IAVS or to inquire about issues of eligibility for project proposals and travel grants. Your donations to the IAVS and EDGG are also highly welcome.

\section{EDGG Bulletin}

\section{Editor-in-Chief: Anna Kuzemko}

(anyameadow.ak@gmail.com)

Deputy Editor-in-Chief: Idoia Biurrun

(idoia.biurrun@ehu.es)

\section{Editorial Board:}

Péter Török (molinia@gmail.com)

Stephen Venn (stephen.venn@helsinki.fi)

Jürgen Dengler (juergen.dengler@zhaw.ch)

Laura Sutcliffe (sutcliffe.laura@gmail.com)

We aim to provide four nice issues of the Bulletin of the Eurasian Dry Grassland Group per year. We publish research papers, announcements and reports on the activities of the group, including Eurasian Grassland Conferences and Field Workshops, reviews of new books, as well as many other materials related to grassland research and conservation. We try to make our Bulletin as interesting and informative for our readers as possible.

You are most welcome to submit your Research papers, Reviews or Reports, as well as any information concerning the study and conservation of grasslands that you would like to share with other members of the group. You can also provide information about your recent publications and events that 


\section{News}

you or your institutions organize. You also have the opportunity to publish your photos of grassland plants, animals or landscapes in the Bulletin.

\section{EDGG Website}

Editor-in-Chief of the Website: Didem Ambarlı (didem.ambarli@gmail.com)

Deputy Officer: Idoia Biurrun

(idoia.biurrun@ehu.es)

We are responsible for the management of the EDGG and the conference homepages. In two years time, we plan to transfer the EDGG homepage to a new server, launch the EDGG homepage and the conference website with a new design, functionalities, updated pages and a pdf database for easy access to all EDGG-related publications. The new homepage will be easy to manage, update and secure source of information with an attractive and mobile-friendly layout.

You are welcome to send your announcements and news related to your recent publications to be posted in the homepage. Furthermore, we would be happy to hear your opinions about further improvement of this media.

\section{Eurasian Grassland Conference Coordinator}

Officer: Michael Vrahnakis (mvrahnak@teilar.gr)

Deputy Officer: Didem Ambarlı

(didem.ambarli@gmail.com)

We work on the organization and implementation of annual conferences of EDGG. This involves finding potential local organizers, setting a schedule for advertising the event, and supporting local organizers in developing a programme, organizing sessions, excursions, workshops and keynote talks, advertising the event; organizing young investigator prizes and IAVS travel grants.

You are welcome to host future conferences. EDGG is willing to hold the conferences anywhere in the Palaearctic region, especially outside Europe, to attract more non-European members and to experience grassland landscapes of Asia and north Africa. Furthermore, please send your suggestions to improve the EGC further.

\section{Special Feature Coordinator}

Officer: Jürgen Dengler (juergen.dengler@zhaw.ch)

Deputy Officer: Péter Török (molinia@gmail.com)
We arrange cooperation with international journals to publish Special Features/Issues (SFs/SIs) on topics related to biodiversity, ecology and conservation of Palaearctic Grasslands. These involve both our regular series in the journals Tuexenia and Hacquetia and one-off Special Issues in journals such as Biodiversity and Conservation, Agriculture, Ecosystems and Environment or Applied Vegetation Science. For such SFs/SIs we plan the overall outline, negotiate with the journals and appoint teams of guest editors (sometimes also involving ourselves). Beyond that, we are also responsible for EDGG book productions, including the planning of a future multi-volume book on Palaearctic grasslands.

You can contact us if you would like to know whether there is a suitable ongoing SF/SI for the submission of your manuscript or if you would like to suggest a topic for a future SF/SI.

\section{Field Workshop Coordinator}

Officer: Jürgen Dengler (juergen.dengler@zhaw.ch)

Deputy Officer: Idoia Biurrun (idoia.biurrun@ehu.es)

We search for potential hosts for future EDGG Field Workshops in nice and understudied grassland regions of the Palaearctic and, once they are approved, collaborate on planning the workshop. We ensure that the standardised EDGG sampling protocol is applied, while at the same time soliciting additions to this (e.g. sampling of additional taxa). It is also within our responsibility to maintain the data of the EDGG Field Workshops, provide them to collaborative databases and to facilitate their utilization in research studies and publications.

You are welcome to contact us if you (a) are interested in hosting one of the future Field Workshops or (b) you would like to utilize existing Field Workshop data for a research project.

\section{Facebook Group}

Officer: Anna Kuzemko (anyameadow.ak@gmail.com)

Deputy Officer: Stephen Venn

(stephen.venn@helsinki.fi)

We aim to enhance the rapid dissemination of information to our members about EDGG activities.

You can visit us https://www.facebook.com/ groups/938367279561202/ to join the group and participate in the discussions or initiate new ones. 


\section{EGC 2018}

\section{5th Eurasian Grassland Conference \\ 4-8 June 2018, Sulmona (Italy)}

COOPERATING FOR GRASSLAND CONSERVATION

First Call
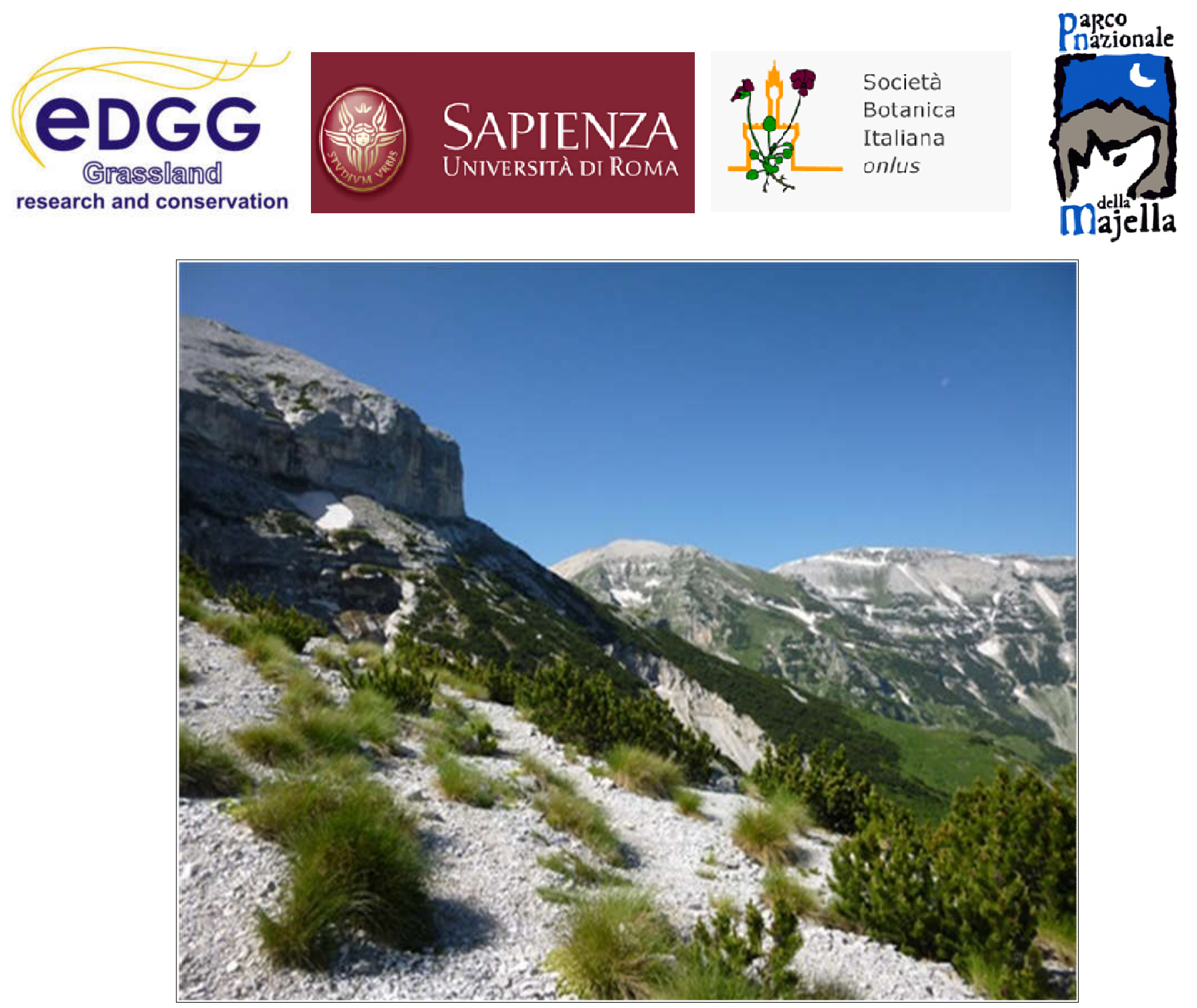

Photo: G. Ciaschetti

The 2018 Eurasian Grassland Conference will take place from $4^{\text {th }}$ to $8^{\text {th }}$ June 2018 in Sulmona, a town in the heart of the Italian Apennines.

It will be the $15^{\text {th }}$ annual conference of the EDGG, which aims to promote exchange and collaboration between those interested in all aspects of semi-natural and natural grassland re- search and conservation across the Palaearctic biogeographical realm.

The main topic of the conference will be the conservation of grasslands through transdisciplinary and transnational cooperation. The conference aims to create a firm basis for the establishment of a network of collaboration within the EDGG. 


\section{Main topic of the conference}

\section{Cooperating for grasslands: from habitat interpreta- tion to conservation measures}

Grasslands are being addressed by a large number of projects aimed at conserving their biodiversity and the wide range of ecosystem services they provide. Still, these projects are jeopardized by the challenges that derive from the intrinsic features of grasslands: the fine grain at which they should be analysed, the complexity that derives from their extraordinary biodiversity and variability, and their tendency to change rapidly in response to various natural and human drivers. Although local information is particularly important, a set of shared principles, methodologies and procedures would make the efforts to maintain grasslands across the Eurasian continent substantially more effective. The topic of the conference is therefore to address the main grassland conservation issues by establishing a basis for cooperation projects within the framework of the EDGG. The subtopics that are described below aim at stimulating exchange of local and national experiences that represent an example for effective cooperation projects.

\section{Subtopics}

1. Habitat classification and indicators of conservation status:

This session will cover grassland habitat classification, and the assessment of habitat conservation status by means of specific indicators. For habitat classification, a special emphasis will be on the potential use of the large number of vegetation relevés stored in European and global databases. Similarly, special focus will be placed on widely applicable approaches for the identification of appropriate indicators of habitat conservation status.

\section{Grassland threats and pressures:}

Land abandonment, invasive alien species, and climate change are among several important threats to grassland habitats and species. However, how these threats change in relation to environmental conditions and land use legacies is still unclear. This gap in knowledge prevents us from defining practical steps to increase resilience of grasslands across the Eurasian continent. Large-scale cooperation may present a huge opportunity to assess threats through standardized monitoring and survey protocols, as well as to create a framework of threats and pressures for grassland habitats.

\section{Conservation goals and appropriate measures:}

Grassland conservation projects focus on goals related to target species and habitats, but the effectiveness of conservation measures to achieve these goals is often a topic of debate. Conservation goals and measures should be integrated into wider society by positively engaging stakeholders, respecting cultures and the role of traditional knowledge, as well as the economic value of managing habitats and their ecosystem services. Conservation planning should therefore be framed in wider contexts and take into account other plans (such as forest plans, river plans, park plans, etc.). By comparing experiences and approaches with integrated management planning and stakeholder engagement, this session

\begin{tabular}{|c|c|}
\hline \multicolumn{2}{|l|}{ June $4^{\text {th }}$} \\
\hline $14.30-18.00$ & Technical workshop \\
\hline $18.00-20.00$ & Welcome drink \\
\hline \multicolumn{2}{|l|}{ June $5^{\text {th }}$} \\
\hline $9.30-12.00$ & $\begin{array}{l}\text { Session } 1 \text { - Habitat classification and indica- } \\
\text { tors of conservation status }\end{array}$ \\
\hline $12.00-13.00$ & Lunch \\
\hline $13.00-15.30$ & $\begin{array}{l}\text { Session } 2 \text { - Grasslands threats and pres- } \\
\text { sures }\end{array}$ \\
\hline $16.00-18.30$ & $\begin{array}{l}\text { Session } 3 \text { - Conservation goals and appro- } \\
\text { priate measures }\end{array}$ \\
\hline \multicolumn{2}{|r|}{ ( } \\
\hline $8.00-18.30$ & $\begin{array}{l}\text { Mid-conference excursion: from Rifugio } \\
\text { Pomilio to Anfiteatro delle Murelle and } \\
\text { Monte Focalone }\end{array}$ \\
\hline \multicolumn{2}{|l|}{ June $7^{\text {th }}$} \\
\hline $9.30-12.00$ & Session 4 - Setting conservation priorities \\
\hline $12.00-13.00$ & Lunch \\
\hline $13.00-14.00$ & Poster session \\
\hline 14.00 & $\begin{array}{l}\text { Transfer to National Park Operation Center } \\
\text { - Badia Morronese }\end{array}$ \\
\hline $14.30-17.30$ & $\begin{array}{l}\text { Workshops: Four working groups will ad- } \\
\text { dress the four session subtopics to brain- } \\
\text { storm transnational cooperation projects } \\
\text { within the EDGG. }\end{array}$ \\
\hline $17.30-18.30$ & EDGG General Assembly \\
\hline $20.00-22.30$ & $\begin{array}{l}\text { Grassland Party (at the National Park Op- } \\
\text { eration Center - Badia Morronese) }\end{array}$ \\
\hline \multicolumn{2}{|l|}{ June $8^{\text {th }}$} \\
\hline $8.00-18.30$ & $\begin{array}{l}\text { Post-conference excursion (optional) - } \\
\text { From Sant'Antonio (Palena) towards Tavola } \\
\text { Rotonda }\end{array}$ \\
\hline
\end{tabular}

will indicate which factors should be considered to achieve good governance models.

\section{Setting conservation priorities:}

Appropriate choice of priorities of sites/habitats to conserve or restore is essential in order to maximize the effort and money spent. Specific analyses should take into account how priorities can be different at different scales, and should therefore be addressed through a wide range of prioritization methodologies, from spatial analysis to a synthetic analysis of different habitats that will be addressed during this session.

\section{Venue}

The conference will take place in the Auditorium of the Annunziata, in the very heart of the town of Sulmona $(25,000$ inh.). The town is located in the Valle Peligna, a plateau once occupied by a lake that disappeared in prehistoric times (Fig. 1 ). The center of the town is characterized by Piazza Garibaldi. This square, limited on one side by a XIII century aqueduct, has a stunning view of Monte Morrone (2,061 m. a.s.l.), and it is one of the largest squares in Italy. It hosts important events and ceremonies and a traditional market on Wednesdays and Saturdays (Fig. 2). 


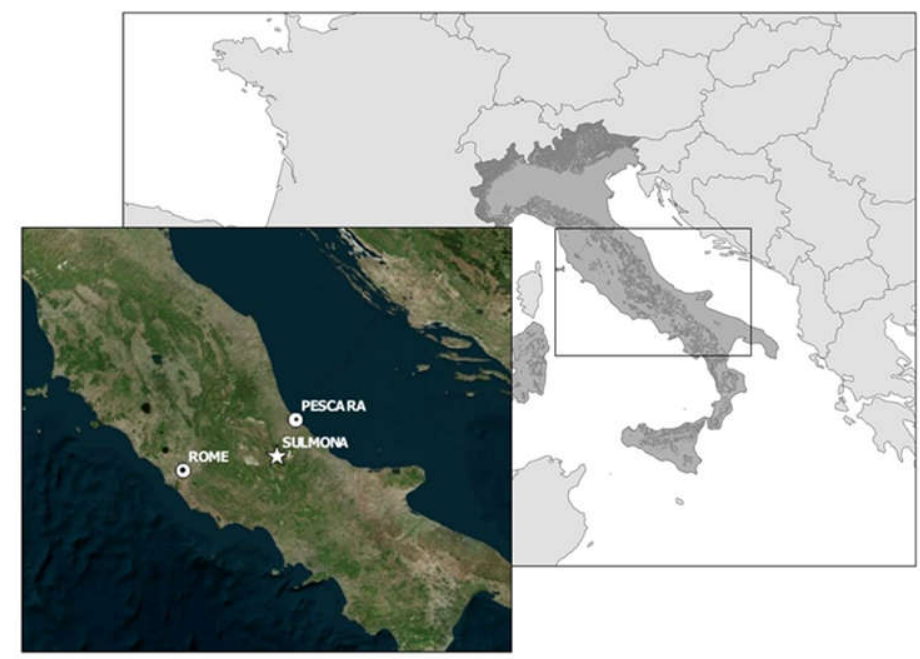

Fig. 1. Map of Italy with indication of the conference venue.

Sulmona is known for being the native town of the Latin poet Ovid, and for being the home of the Italian confectionery known as "confetti".

\section{Excursions}

\section{Mid-conference excursion}

The excursion will start from Rifugio Pomilio (2000 m a.s.I.) and will reach the altitude of about $2650 \mathrm{~m}$ a.s.l. (Monte Focalone) after a stop at the Anfiteatro delle Murelle (Fig. 3). The footpath will cross interesting examples of mesophilous secondary grasslands (dominated by Bromus erectus and Brachypodium genuense).

The subalpine shrublands are represented by Pinus mugo, at the southern limit of its distribution.

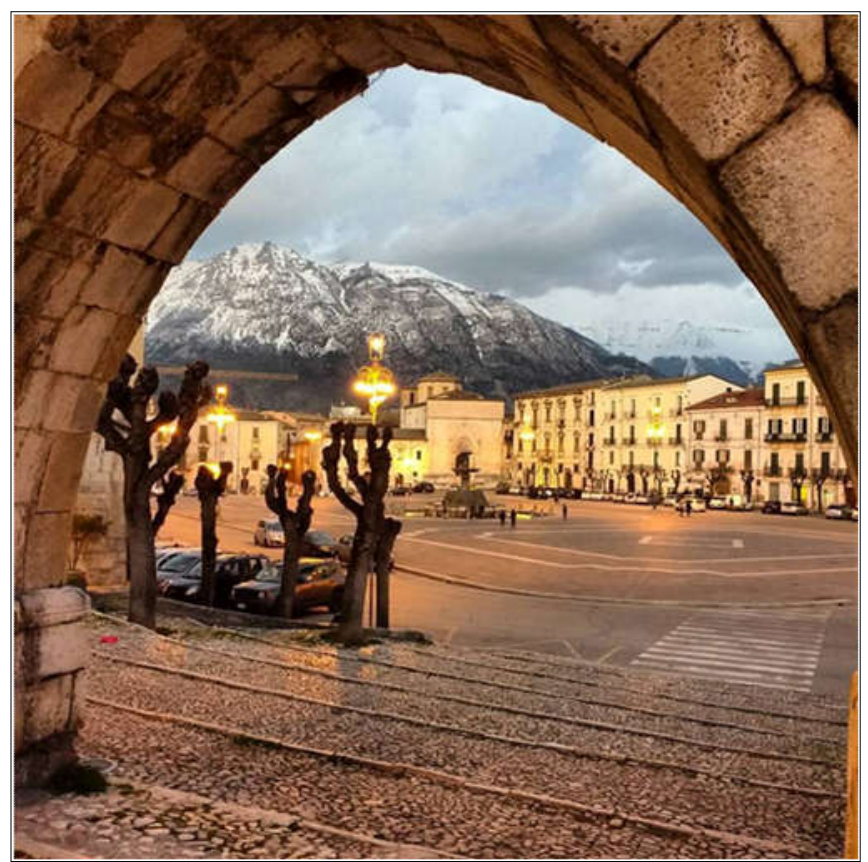

Fig. 2. A view of Piazza Garibaldi and Monte Morrone at sunset. Photo: S. Landersz.
Mountain shoes and clothes, hat and sunscreen will be necessary.

Post-conference excursion (optional)

The excursion will cover a great altitudinal range from about $1000 \mathrm{~m}$ a.s.l. to about $2000 \mathrm{~m}$ a.s.I., in Tavola Rotonda. Along the footpath it will be possible to see the secondary grasslands of the montane belt (dominated by Bromus erectus and Sesleria juncifolia), and the subalpine dwarf shrublands dominated by Arctostaphylos uva-ursi and Juniperus communis var. saxatilis. Finally, we will reach the alpine belt, with primary grasslands dominated by Festuca violacea subsp. italica, and scattered examples of alpine vegetation (Fig. 4).

Mountain shoes and clothes, hat and sunscreen will be necessary.

\section{Technical workshop}

In order to facilitate the work of the participants in establishing new connections and potential cooperation projects the workshop will introduce some funding possibilities, with special reference to the EU but with the possibility of involving other countries. The workshop will focus on LIFE+ and INTERREG programmes, as well as on the Marie-Curie actions addressing researchers. Proposal preparation will be explained and practical examples of successful proposals will be described.

\section{Accommodation}

It should be booked independently by each participant. Sulmona hosts several hotels and bed and breakfast that are advertised on popular hotel search engines. A short list of accommodation will be given in the second circular.

\section{Traveling}

The city may be reached by train or bus from Rome or Pescara. Both these cities have international airports. The transfer from Rome or Pescara can be made by train (www.trenitalia.it/en) or by bus (www.tuabruzzo.it; www.autolineepstar.com). It takes approximately two hours from both cities. Details about the venue and travelling will be available in the second circular.

\section{Registration}

You can register and post your abstract at the web page of the conference, which is expected to be launched soon (all EDGG members will be informed by e-mail when the website will be available).

Fees will be communicated in the second circular.

The fee covers: attendance to the technical workshop, attendance to the scientific sessions, coffee breaks and lunches between the sessions, grassland party, attendant pack, transport and lunch pack for the mid-conference excursion. 

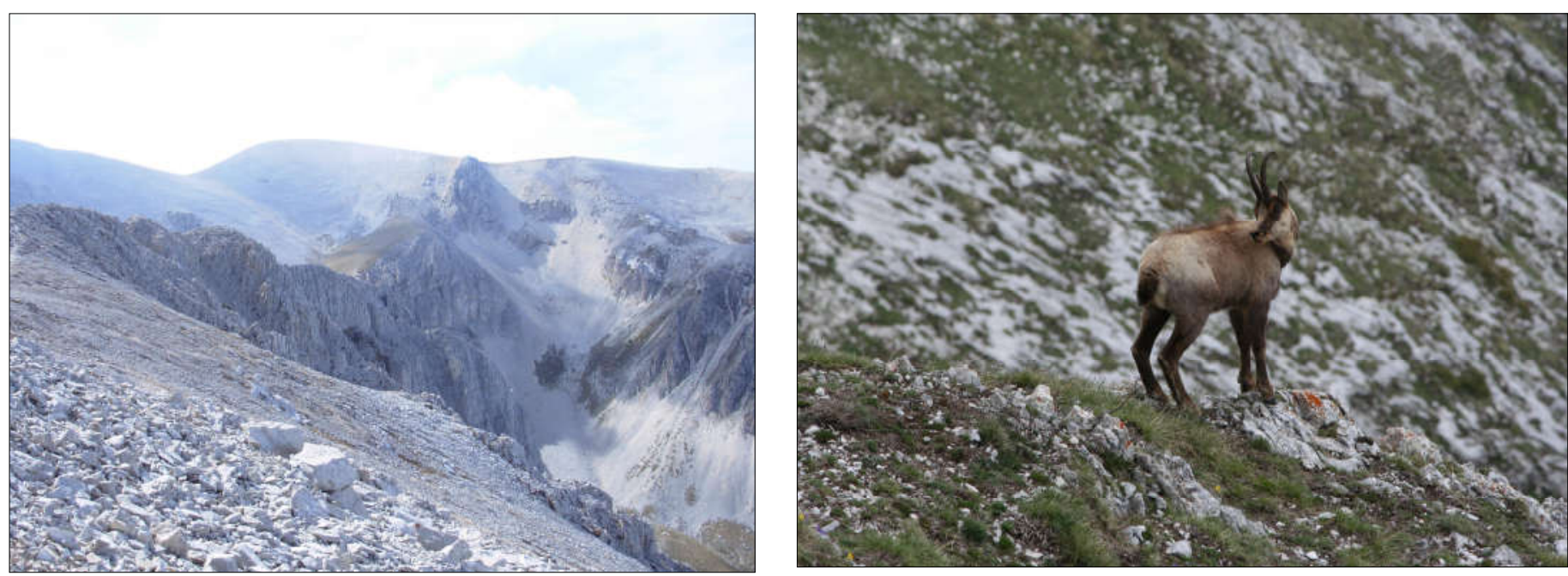

Fig. 3. Anfiteatro delle Murelle (one of the mid-stops of the Excursion 1) and a Chamois frequenting the site.

Photo: A. Guerri.

An additional fee of 30 euros will be charged for the postconference excursion (includes transport and lunch pack).

Fees should be paid to Società Botanica Italiana onlus - iban: IT $90 K 0335901600100000019$ 636. The object of the conference should be specified as: EDGG Conference - name of the participant.

\section{Important dates}

Deadline for early bird registration: 28 February 2017

Deadline for abstract submission: 28 February 2017

Deadline for registration: 30 April 2017

\section{Grants}

We hope to offer a limited number of travel grants for IAVS members. To qualify, active participation at the conference (oral presentation or poster) is required and priority will be given to young scientists with financial constraints. Grants can be applied during registration, including a short motivation letter. More details will be given in the Second Circular.

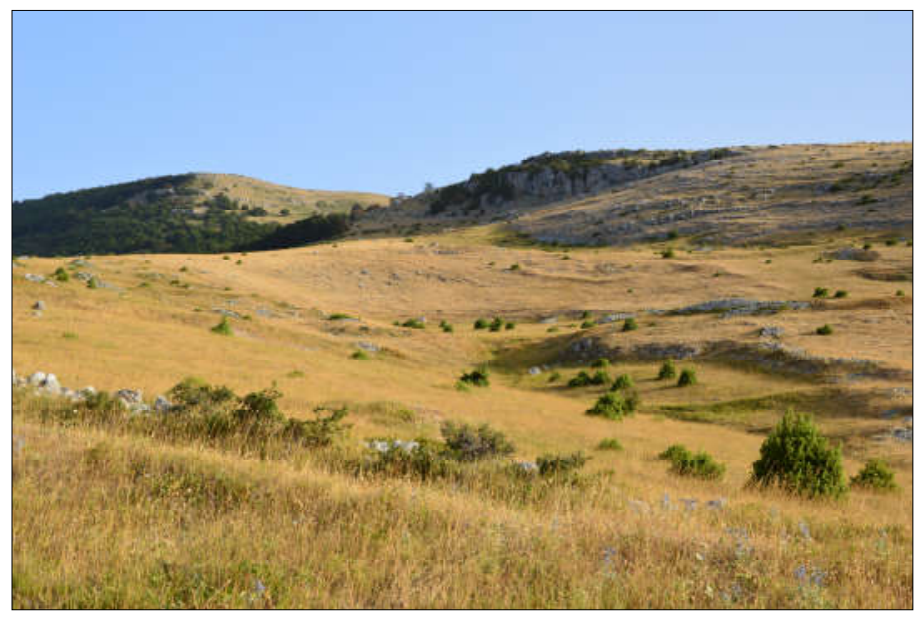

Fig. 4. A view from the slope towards Tavola Rotonda.

Photo: G. Ciaschetti.

\section{Conference publications}

As in previous years, there will be Special Features (SFs) with selected contributions from the conference in international, peer-reviewed journals, guest-edited by EDGG members.

\section{Young Investigator Prizes}

As in previous years, prizes will be awarded to young scientists for excellent presentation of their research (talk or in poster form). For these purposes, young scientists (less than 35 years old) will be asked during registration if they wish to participate in the contest.

\section{Visas}

In case you need an invitation, please refer to the contact persons.

\section{Contact persons}

Sabina Burrascano - sabina.burrascano@uniroma1.it Giampiero Ciaschetti-giampiero.ciaschetti@parcomajella.it Eleonora Giarrizzo - eleonora.giarrizzo@uniroma1.it

\section{Local Organizing Committee}

Sabina Burrascano, Rome, Italy, sabina.burrascano@uniroma1.it

Giampiero Ciaschetti, Chieti, Italy, giampiero.ciaschetti@parcomajella.it Eleonora Giarrizzo, Rome, Italy, eleonora.giarrizzo@uniroma1.it Emanuela Carli, Rome, Italy

Eva Del Vico, Rome, Italy Laura Facioni, Rome, Italy EDGG Conferences Coordinators:

Michael Vrahnakis, Karditsa, Greece, mvrahnak@teilar.gr

Didem Ambarlı, Düzce, Turkey, didem.ambarli@gmail.com 


\section{Announcement}

\section{1th EDGG Field Workshop}

\section{Eastern Alps, Austria}

First Call

The 11th EDGG Field Workshop will take place in Austria from 6th to 13th of July 2018. We will start and finish in Graz (airport).

The main idea of this workshop is to start a resampling of Braun-Blanquet's (1961) study of the vegetation of the "Inneralpine dry valleys" but with a standardised sampling approach (Dengler et al. 2016) and followed by state-of-theart analyses of biodiversity patterns. We also want to use the data as a contribution to broad-scale vegetation classification in Europe because a modern treatment of the dry grassland vegetation of the Alps is generally missing. It is a good opportunity to initiate such a complex project in the easternmost part of the Alps, where the climatic situation (aridity in summer) is not as extreme as in the deep valleys of the Western Alps. The expedition is also open to zoologists who want to sample invertebrate groups in parallel to the botanists on the same plots.

We will start in the Styrian Mur valley, where we have mostly rocky grasslands of the Stipo pulcherrimae-Festucetalia pallentis order and will then move to East-Tyrol to the village

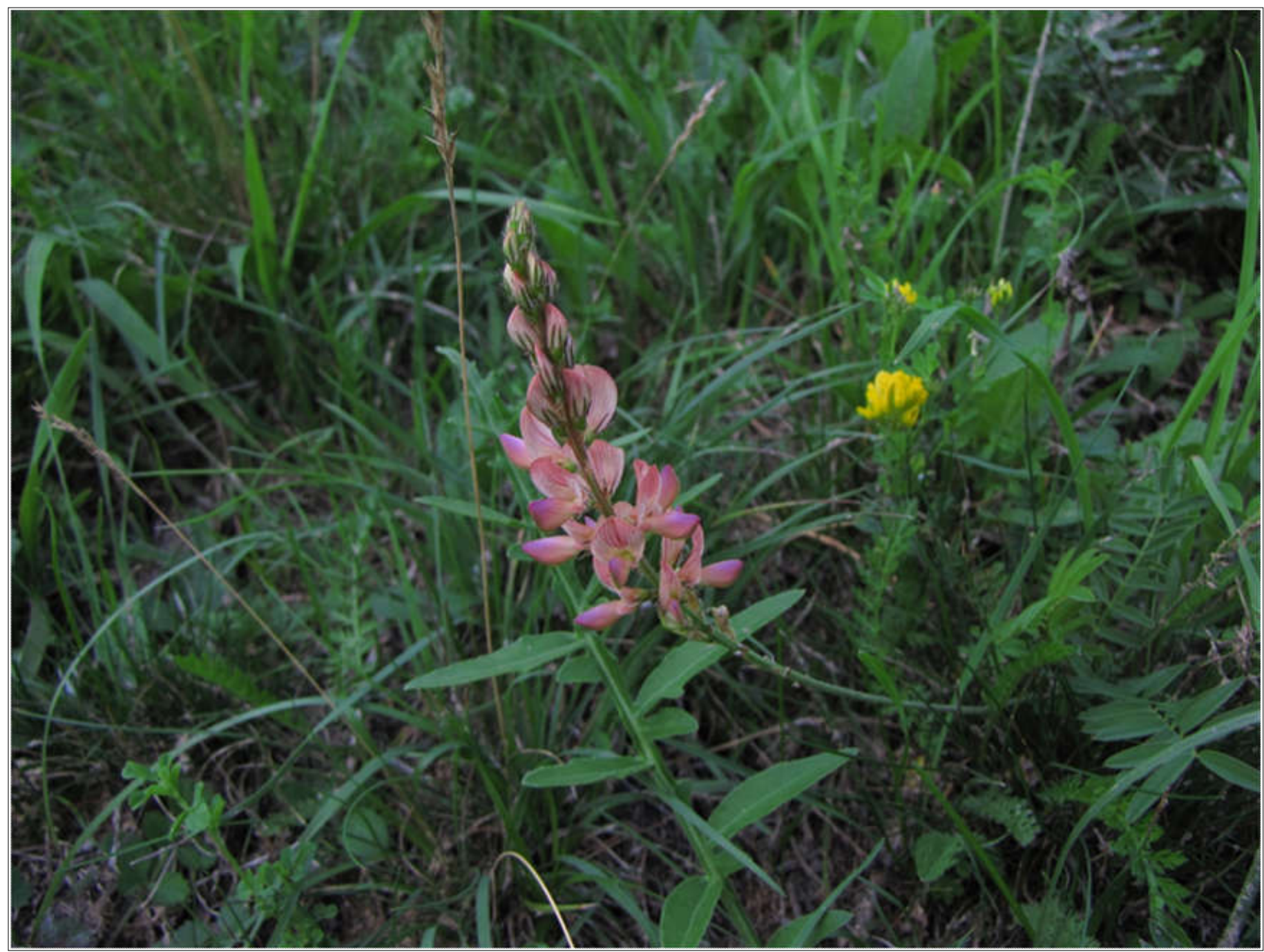

Fig. 1. Onobrychis arenaria subsp. taurerica, Virgen. Photo: Martin Magnes. 
Virgen, with vegetation of the Festucion valesiacae alliance (Fig. 1). The highlight will be the upper Inn-Valley in Tyrol southeast of Landeck where we can study the vegetation of the Stipo-Poion xerophilae alliance in the "Natural Park Kaunergrat" near the villages Fließ and Kauns. Our way back to Graz will guide us through Austria's southernmost province of Carinthia (Fig. 2).

The expected maximum costs of approximately $€ 700$ will include accommodation, full meals and transport from and to the Graz airport. To reduce costs, we will use two microbuses, at least one from the University of Graz for the transport. Because of that the number of participants is limited to 16 .

A detailed call with possibility to register will follow in the next issue of the Bulletin. If you have questions before that, you can send an e-mail to martin.magnes@uni-graz.at.

\section{References}

Braun-Blanquet, J. 1961. Die inneralpine Trockenvegetation. Von der Provence bis zur Steiermark. Geobotanica Selecta 1: 1-273.
Dengler, J., Boch, S., Filibeck, G., Chiarucci, A., Dembicz, I., Guarino, R., Henneberg, B., Janišová, M., Marcenò, C., (...) \& Biurrun, I. 2016. Assessing plant diversity and composition in grasslands across spatial scales: the standardised EDGG sampling methodology. Bulletin of the Eurasian Grassland Group 32: 13-30.

Local organisers:

Martin Magnes, Graz, Austria,

martin.magnes@uni-graz.at

Philipp Kirschner, Innsbruck, Austria,

philipp.kirschner@gmail.com

Helmut Mayrhofer, Graz, Austria,

helmut.mayrhofer@uni-graz.at

EDGG Field Workshop Coordinators:

Jürgen Dengler, Wädenswil, Switzerland,

juergen.dengler@zhaw.ch

Idoia Biurrun, Bilbao, Spain,

idoia.biurrun@ehu.es

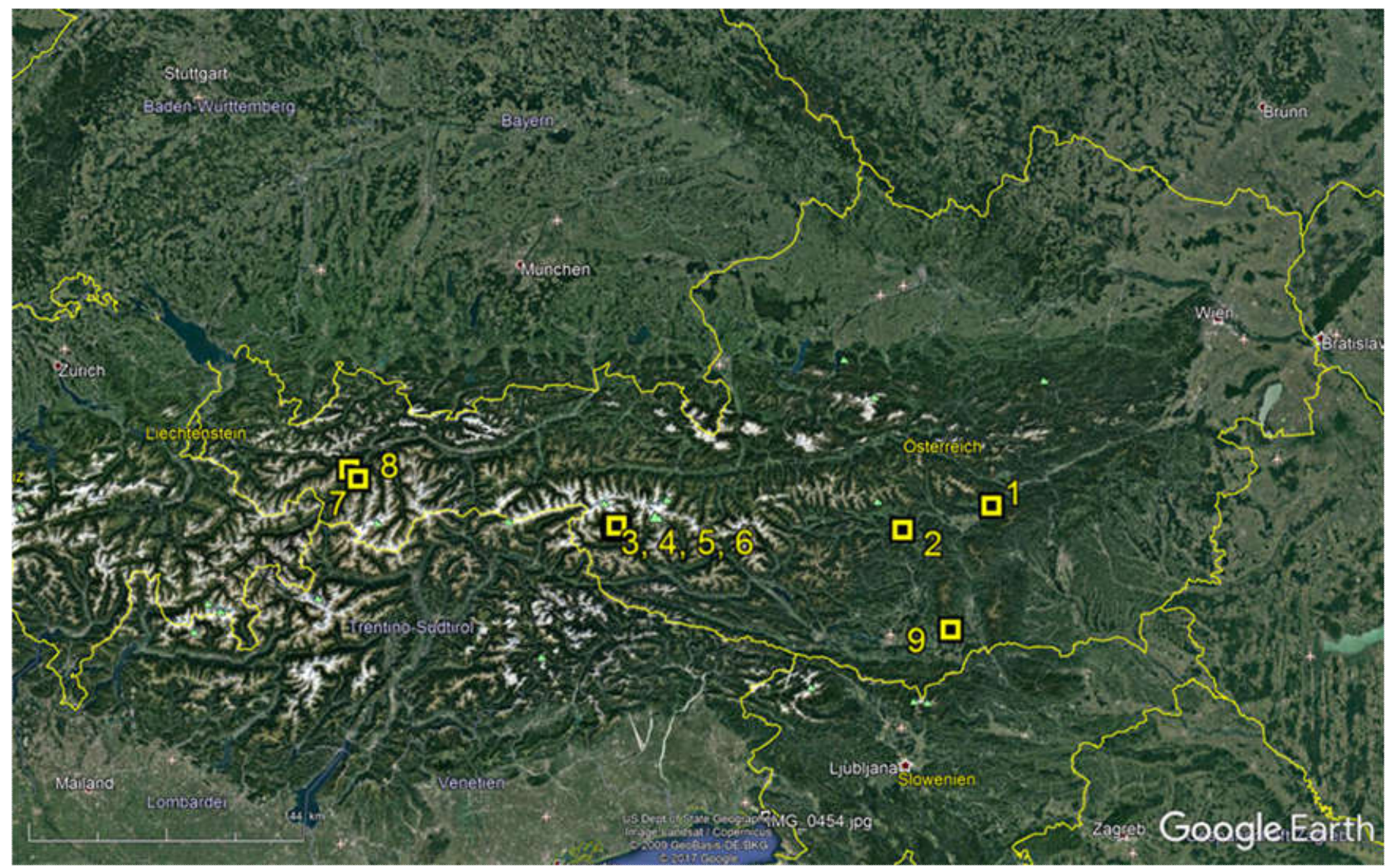

Fig. 2. Investigation areas of the $11^{\text {th }}$ EDGG Field Workshop in Austria (Google Earth, 2017-11): 1 Gulsen near Kraubath, 2 Pux, 3 Virgen: castle hill Rabenstein, 4 Virgen: castle hill Obermauern, 5 Virgen: haymeadow, 6 Virgen: subalpine haymeadow, 7 Fließ: Fließer Sonnenhänge, 8 Kauns: dry grasslands, 9 Griffen: castle hill. 


\title{
Report from the 14th Eurasian Grassland Conference
}

\author{
4-11 July 2017
}

\section{in Riga, Latvia and western Lithuania}

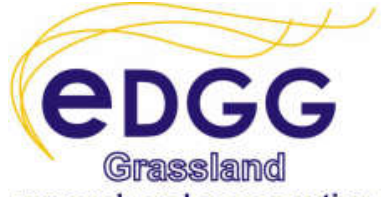

research and conservation

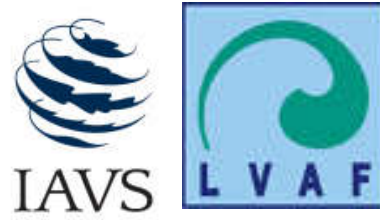

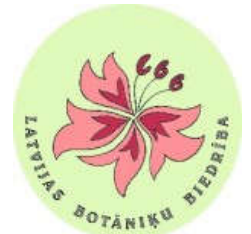

\section{Latvijas vides aizsardzības fonds}
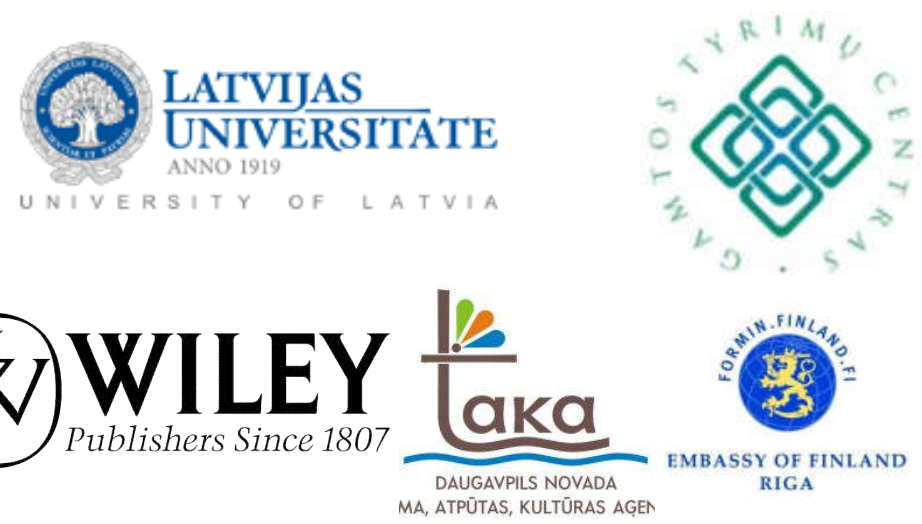

The 14th Eurasian Grassland Conference (EGC) "Semi-natural grasslands across borders" was held in Riga, Latvia and Western Lithuania, 4-11th July 2017. In addition to the main programme, there were four optional events: a preconference workshop on R program for beginners (led by associated professor Didzis Elferts from the University of Latvia) and three excursions before, during and after the conference.

The conference took place in the newly built Academic Center for Natural Sciences of the University of Latvia (opened in September, 2015) and was attended by 92 participants from 19 countries. Thanks to the EDGG's mother organization IAVS, several participants were supported with travel grants. The Dean prof. Zaiga Krišjāne of the Faculty of Geography and Earth Sciences (hosts of the event), and the Director General of the Nature Conservation Agency Juris Jātnieks welcomed all the participants at the opening ceremony.

The main focus of the EGC was to place emphasis on cases in which grassland ecosystems are shared between man-made and natural geographical, political and ecological borders. Recent research results were presented by linking them to practical management and policy that contribute to sustainability of natural and semi-natural grasslands. These topics were highlighted by two keynote speakers: Aveliina Helm from the Unversity of Tartu, Estonia, and Irina Herzon from the University of Helsinki, Finland.

In her keyote lecture entitled In Hands of Farmers and Society: Fate of the Semi-Natural Grasslands in the Boreal Region, Irina Herzon summarised the established impacts of EU policy on semi-natural grasslands. She gave an excellent overview of the most recent policy developments of relevance, including the reform of the Common Agricultural Policy in 2013. Irina presented the extinction vortex model a self-reinforcing circle leading to extinction of semi-natural grasslands in the region and highlighted the possible solutions to overcome this process. Conservaton policy needs to perceive semi-natural grasslands as socio-ecological systems. Facilitating recoupling semi-natural grassland ecosystems with a new kind of social system is needed to preserve these ecosystems.

Aveliina Helm sumarised the findings of her research group at the Institute of Ecology and Earth Sciences (University of Tartu) on the development and maintenance of species diversity of grasslands habitats in Europe, especially focusing on landscape-scale patterns and the existence of time-lags in species response to habitat changes. Aveliina highlighted results of the research from ten separate regions in central and northern Europe to identify regions where an extinction debt has already been paid and where it still remains to be settled. The lecture provided also an excellent overview of the activities carried out during the project "LIFE to Alvars" of EC LIFE+ Nature programme. The project aims to restore 2500 hectares of overgrown calcareous alvar grasslands in Estonia. Aveliina discussed the possible effects of landscape-scale restoration activities in maintaining grassland species diversity and related ecosystem services.

In total, there were 23 oral and 20 poster presentations (Rūsiṇa 2017a, http://www.edgg.org/pdf/EGCabstracts/ 2017/Book of Abstracts 14EGC.pdf). We would like to congratulate the winners of the Young Investigator Prizes for outstanding talks or posters by researchers under the age of 35: Philipp Kirschner, Kristina Plenk and Alina Baranova for best oral presentation, and Iwona Dembicz, Kristina Plenk and Yulia Rozenblit for best poster presentation. Please use this link to download some of the talks and posters: http://www.edgg.org/pdf/EGC2017/contributions.rar. 


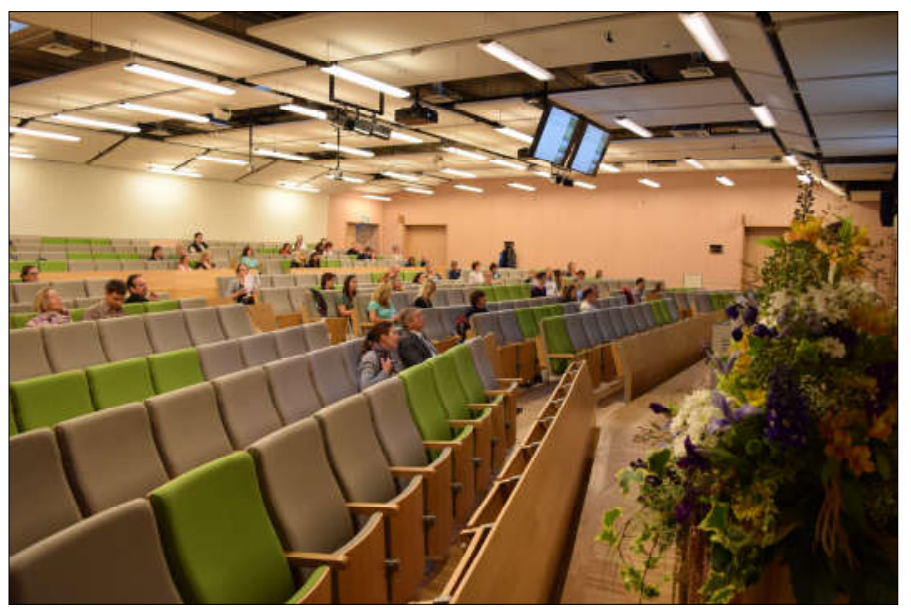

During the conference presentations. Photo: Solvita Rūsina.

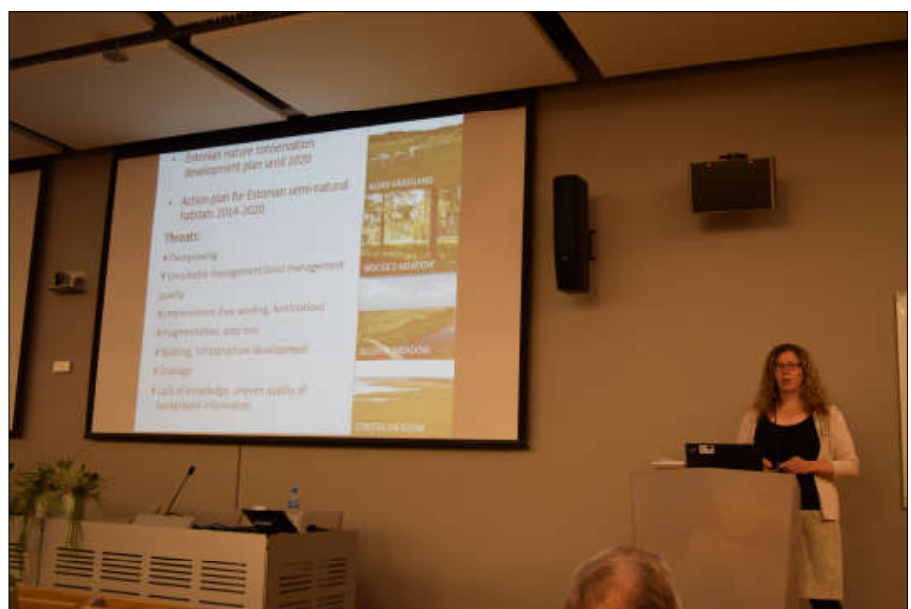

Keynote lecturer Aveliina Helm. Photo: Solvita Rūsinga.

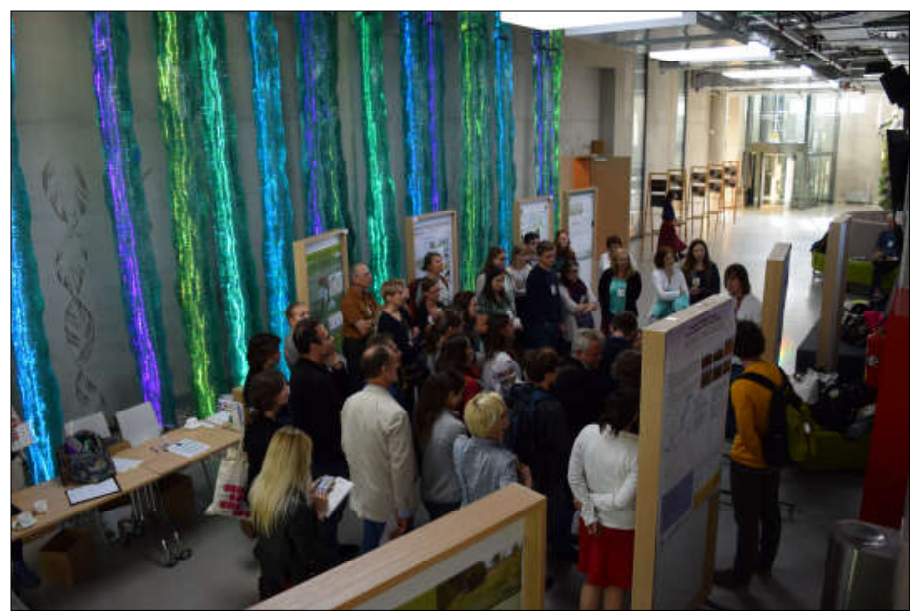

Poster session. Photo: Solvita Rūsina.

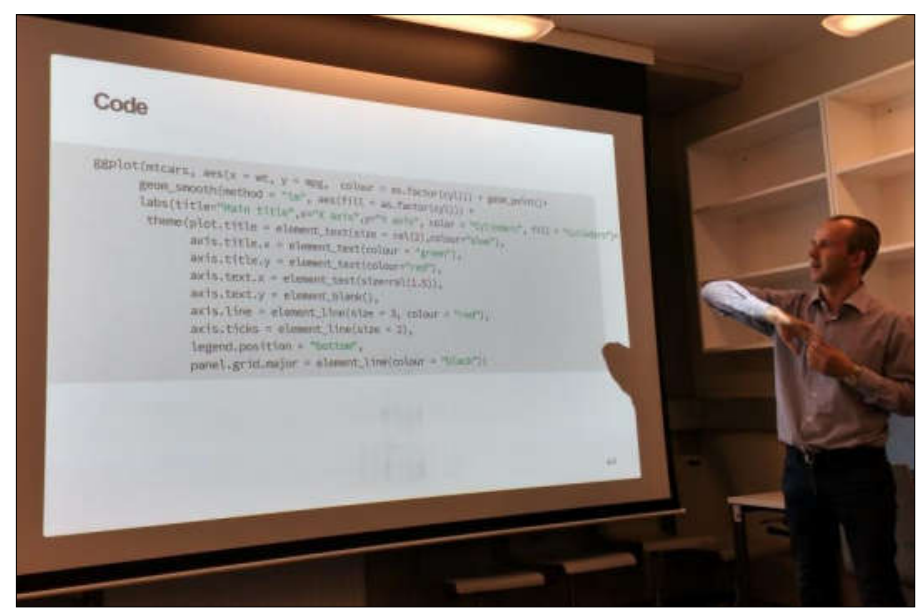

Didzis Elferts holds a workshop "Introduction to the ggplot2 graphical system". Photo: Didem Ambarlı.

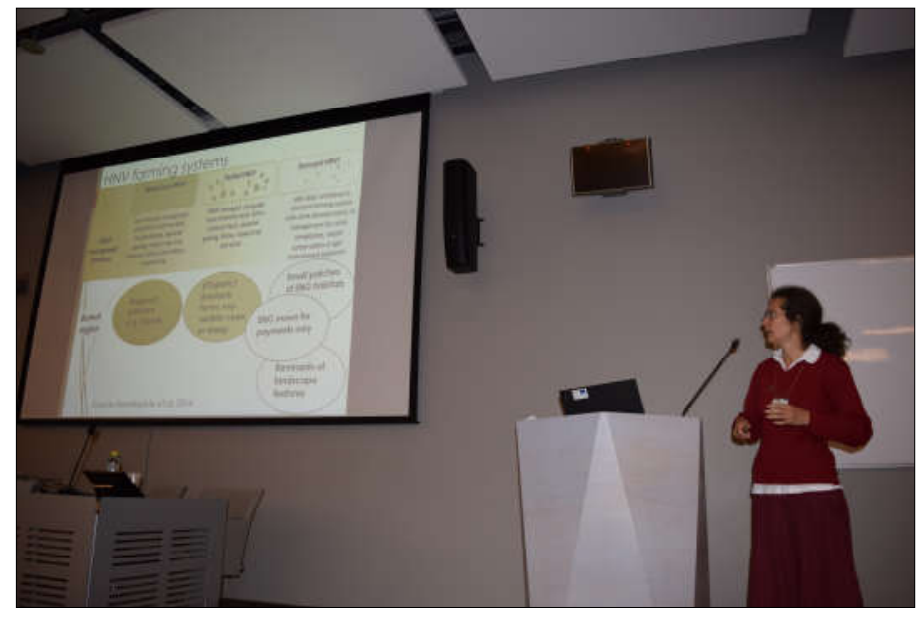

Keynote lecturer Irina Herzon. Photo: Solvita Rūsiṇa.

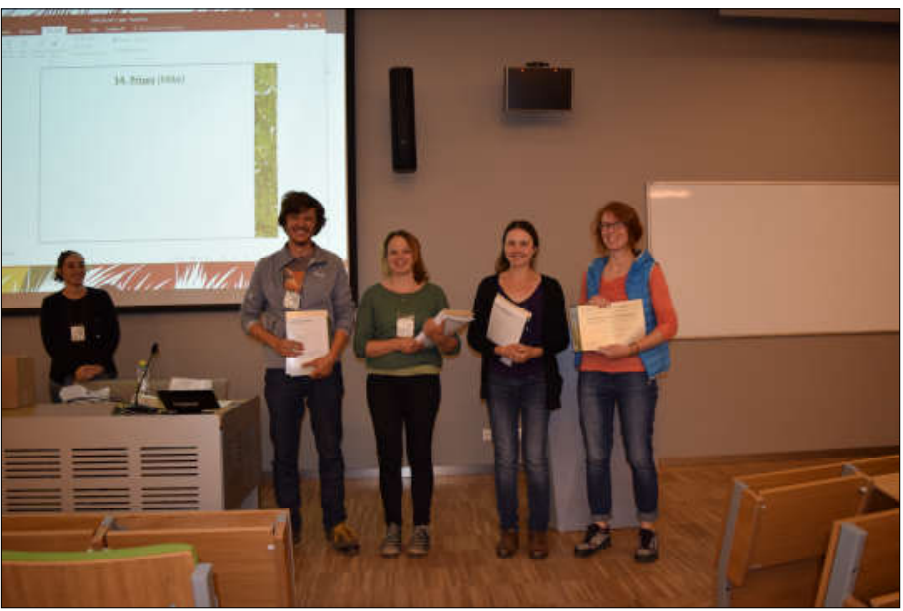

Winners of the Young Investigator Prizes. Photo: Solvita Rūsina. 
Three excursions were organized during the conference. Two excursion guides were prepared for this purpose: one for the post-conference excursion (Rašomavičius et al. 2017, the link: http://www.edgg.org/pdf/EGCabstracts/2017/Post Conferen ce Excursion small.pdf) and another for the pre- and midconference excursions composed of a collection of scientific articles (Rūsinna 2017b, http://www.edgg.org/pdf/EGC

abstracts/2017/MidexcursionEGC2017.pdf). The latter includes articles related to semi-natural grasslands in Latvia and provides a deeper insight into some of the most diverse Natura 2000 sites in terms of semi-natural grassland flora, vegetation and fauna. The aim of the book was to introduce the readers to the biodiversity, management and restoration of semi-natural grasslands in the Natura 2000 sites included in the conference field excursions. The sites' geographical locations, species composition, semi-natural grassland diversity, landscape history, cultural heritage, and contemporary grassland management solutions were included. The intention was to present not only the basic information and lists of selected plant species, but also to show the results of vegetation monitoring and to evaluate the restoration efficiency. The book highlighted both the best practice and problems related to semi-natural grassland management and restoration.

Participants of the pre-conference excursion visited the Eastern Baltic semi-natural grasslands of the Daugava River
Valley. Plant communities include the classes KoelerioCorynephoretea (Koelerion glaucae), Festuco-Brometea (Filipendulo-Helictotrichion), Molinio-Arrhenatheretea (Calthion, Arrhenatherion, Cynosurion), and hygrophilous tall herb communities of the Convolvuletalia sepium along the river banks. A specific plant community with Allium schoenoprasum was a challenging discussion subject for phytosociologists. Rare plant species included Centaurea rhenana, Helichrysum arenarium, Gentiana cruciata, Jovibarba globifera, Allium schoenoprasum, etc. We visited a recently restored site which was overgrown by pines. The second day was devoted to the Dviete River Valley (tributary of the Daugava) with extensive floodplain grasslands (Calthion, Magnocaricion) grazed by semi-wild horses and supporting the rare species Iris sibirica, Gladiolus imbricatus, Viola persicifolia and Cnidium dubium.

Participants of the mid-conference excursion visited The Abava River Valley, which is a pearl of calcareous dry grassland diversity in Latvia. Plant communities include the classes Koelerio-Corynephoretea (Armerion elongatae), Festuco-Brometea (Filipendulo-Helictotrichion), Juniperus communis stands on calcareous grasslands, and calcareous fens (Caricion davallianae). Rare plant species include the dry grassland species Astragalus danicus, Carex ornithopoda, Gymnadenia conopsea, Viola collina and Sesleria caerulea, as well as the fen species Carex davalliana, Schoenus ferrugineus, Pinguicula vulgaris, Primula farinosa and Crepis praemorsa.

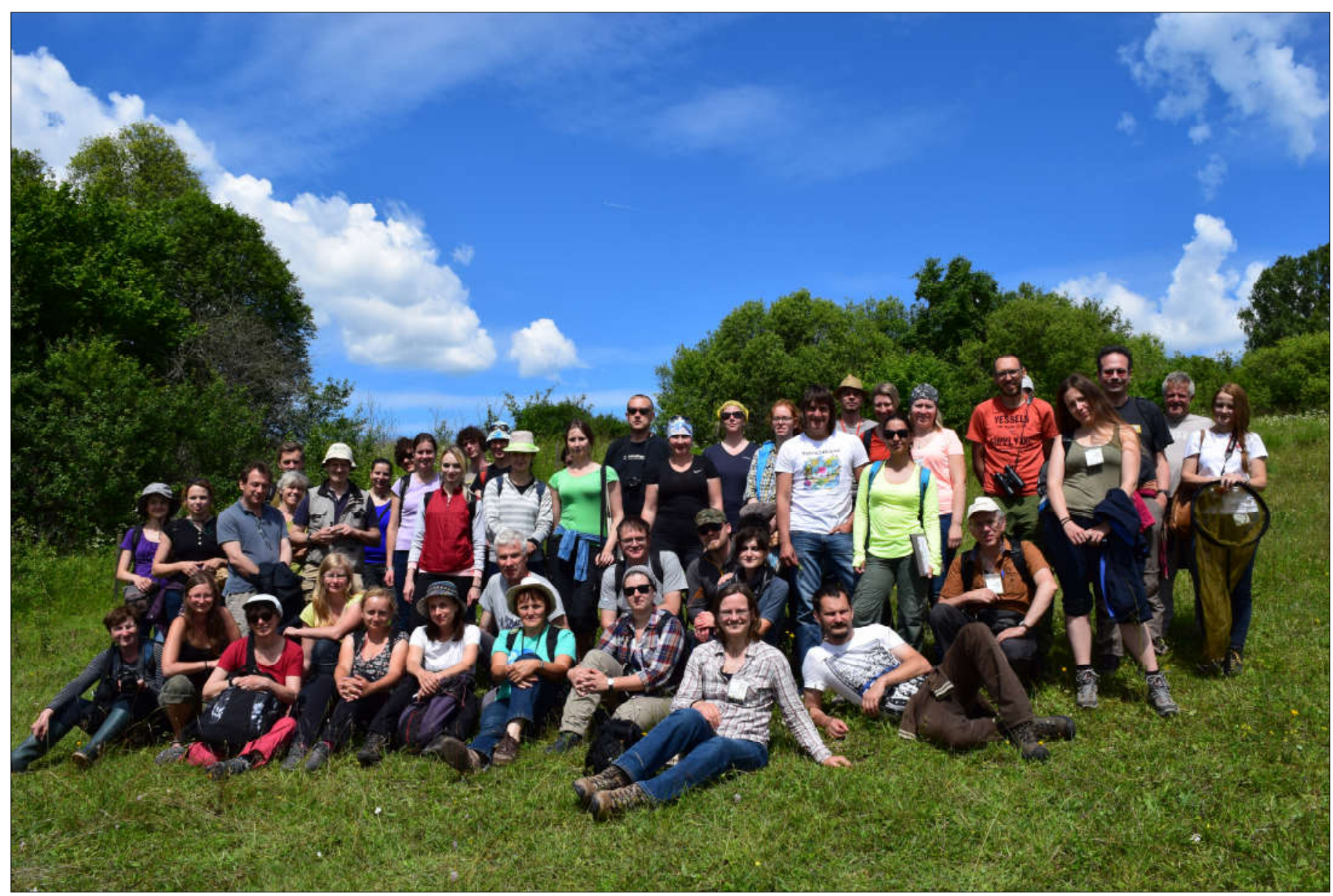




\section{Pre-conference excursion}

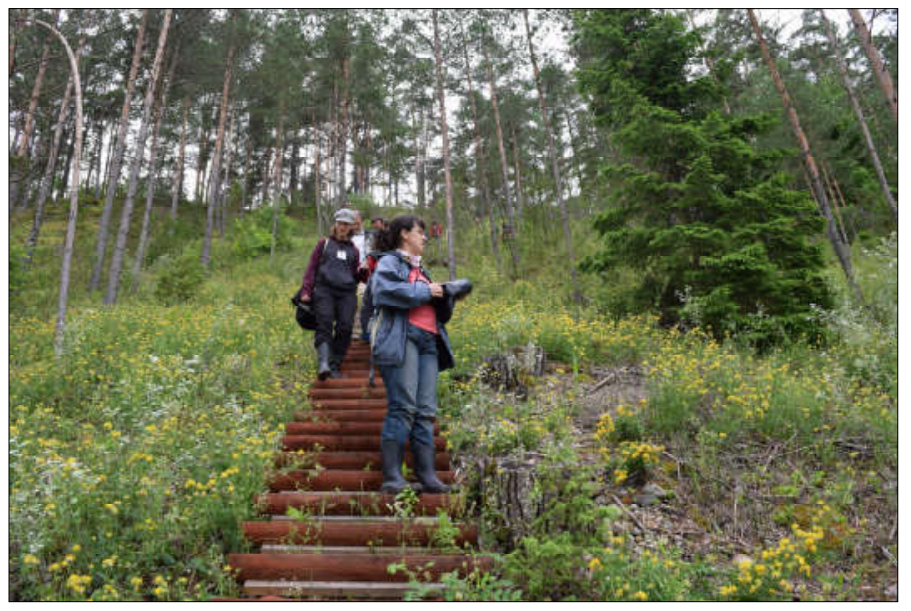

Dry pine forest of the class Pyrolo-Pinetea sylvestris. Photo: Solvita Rūsinga.

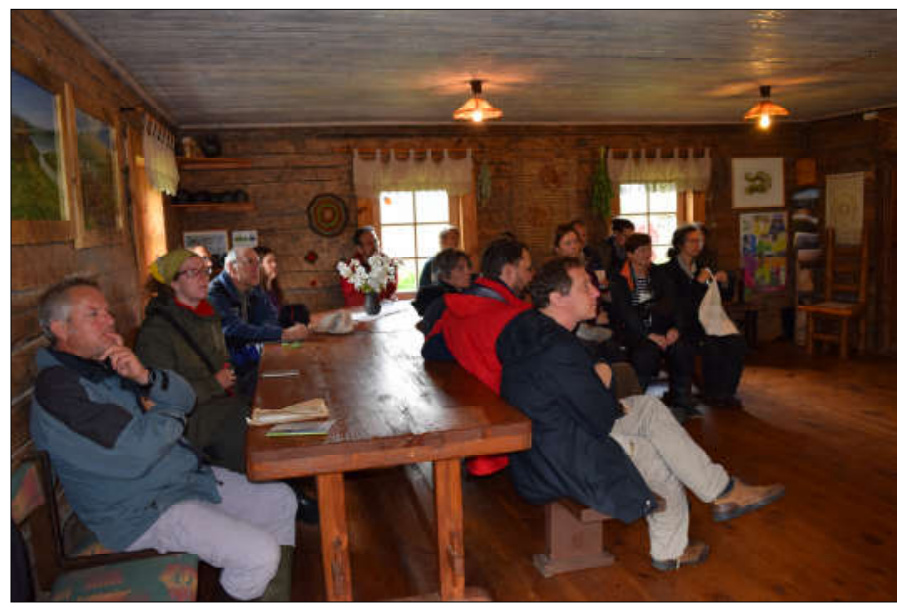

At the Dviete Valley Information Centre "Gulbji". Photo: Solvita Rūsina.

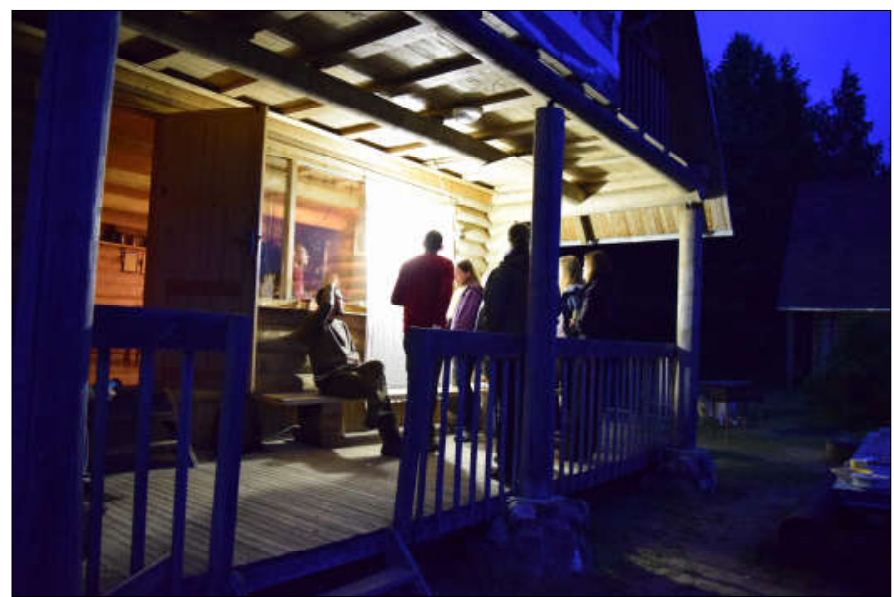

Insect night after the first excursion day. Photo: Solvita Rūsina.

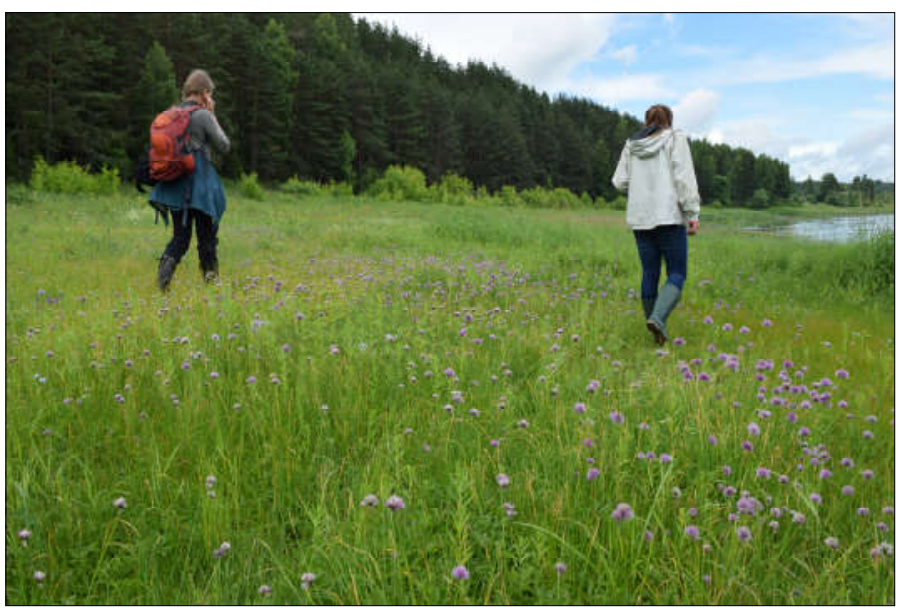

Grassland community with Allium schoenophrasum in the floodplain of the Daugava River. Photo: Solvita Rūsina.

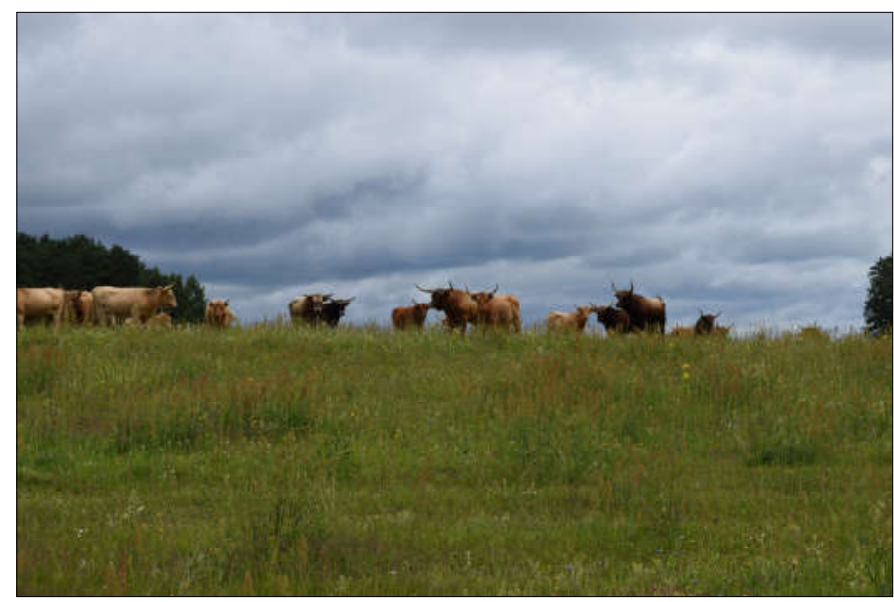

Cattle in the Dviete floodplain grasslands. Photo: Solvita Rūsina.

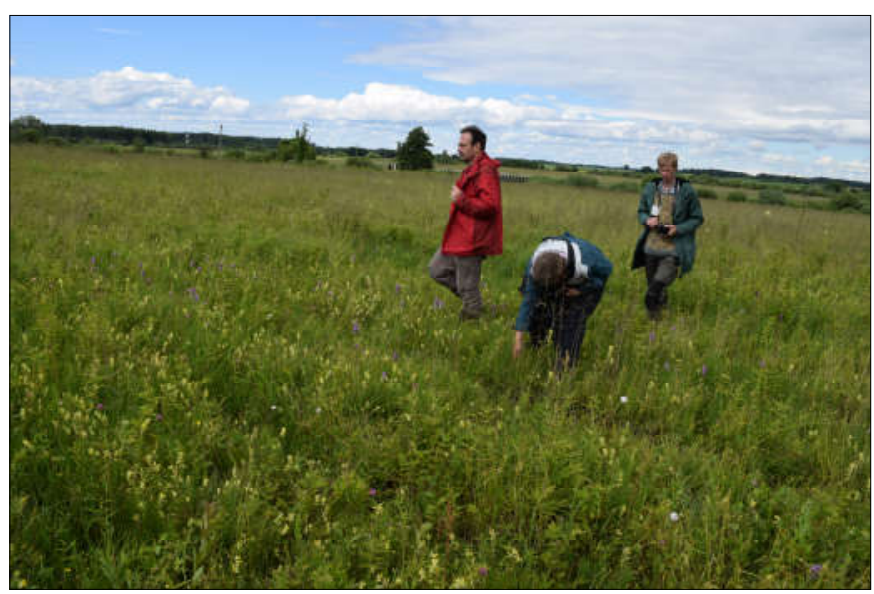

A locality with abundant Dactylorhiza spp. in the Dienvidsusēja River floodplain. Photo: Solvita Rūsina. 


\section{Mid-conference excursion}

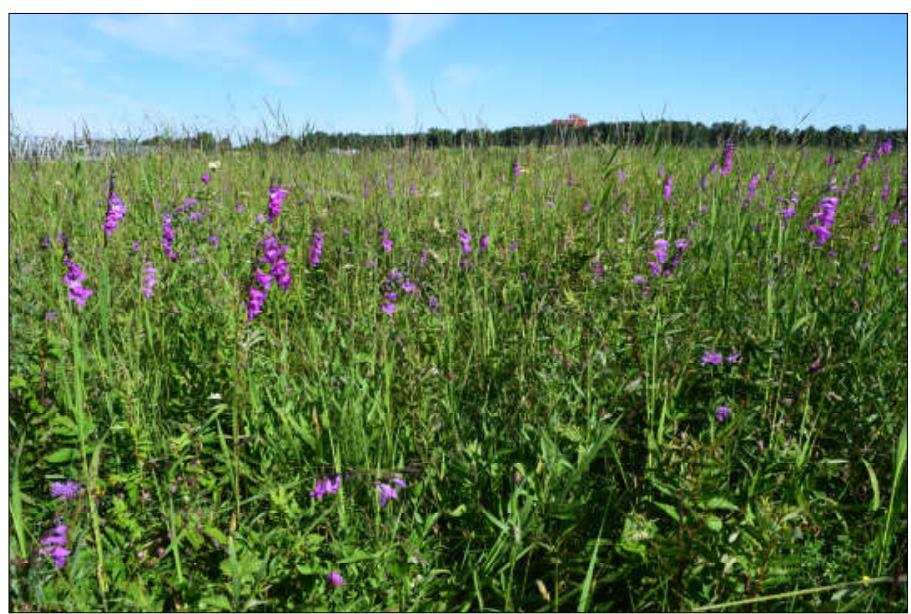

Gladiolus imbricatus in the Lielupe river floodplain grassland. Photo: Solvita Rūsina.

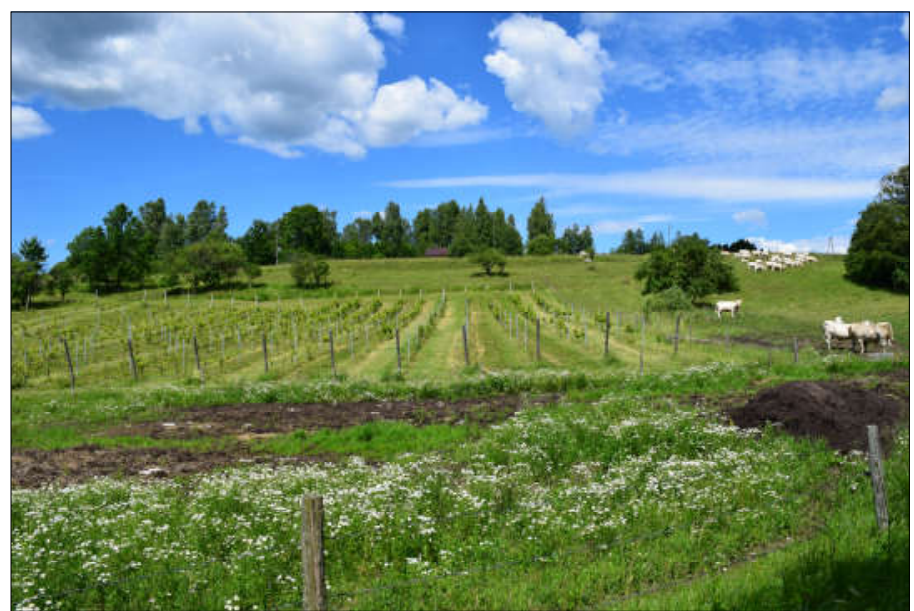

An unusual landscape for Latvia - vineyard of the local varieties of grapes. Photo: Solvita Rūsinga.

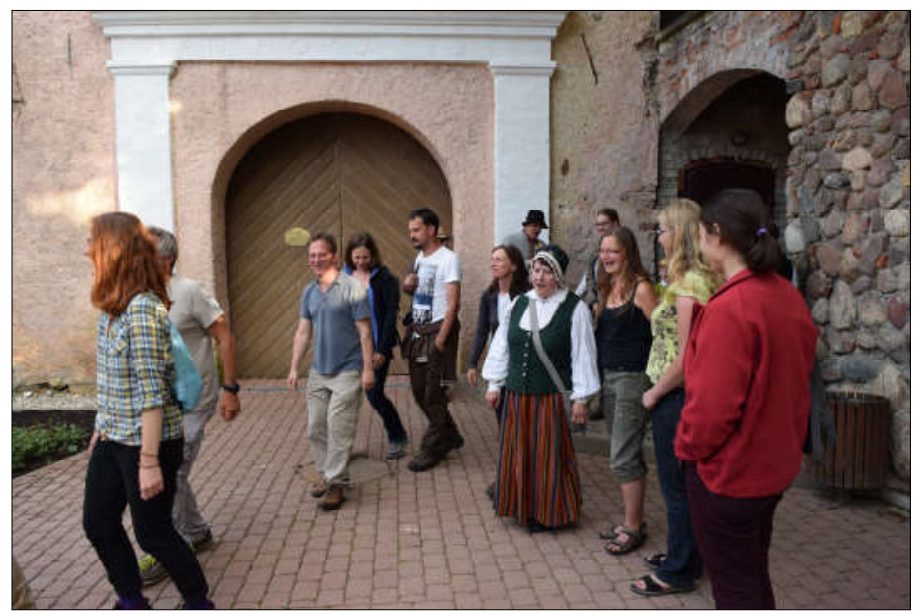

Grassland party. Photo: Solvita Rūsina.

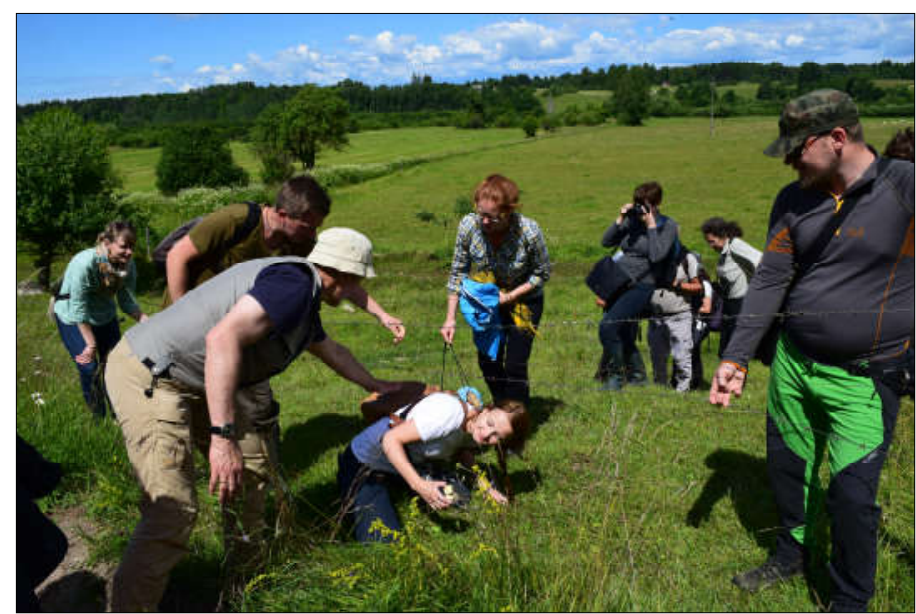

Overcoming the fences. Photo: Solvita Rūsina.

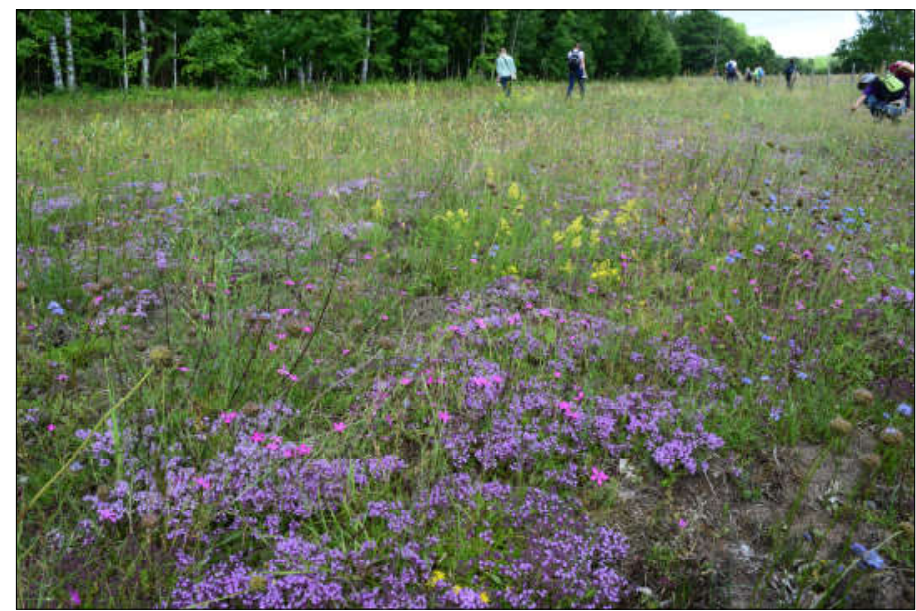

Sandy grassland of the alliance Armerion elongatae with Thymus serpyllum, Jasione montana, Botrychium lunaria. Photo: Solvita Rūsinga.

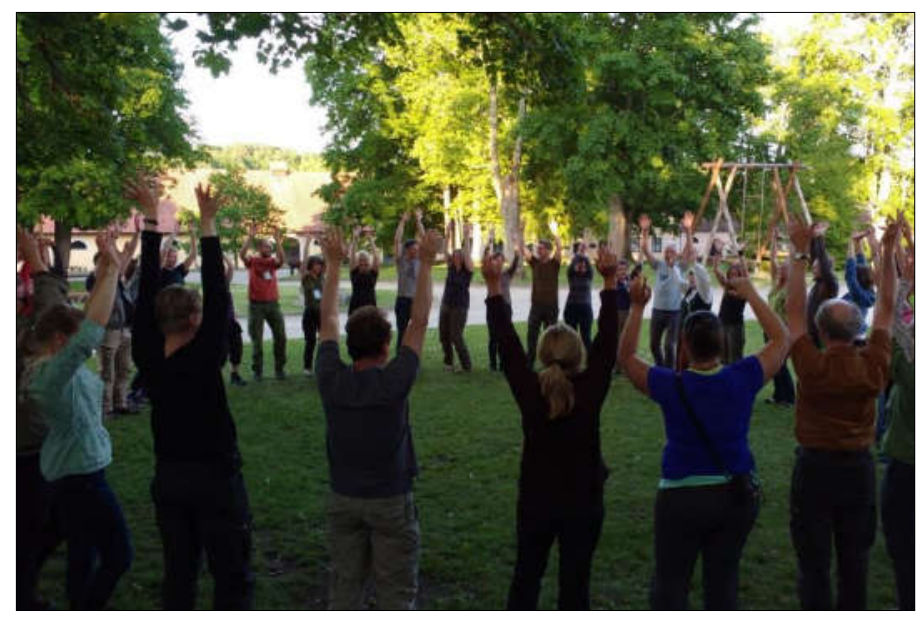

Grassland party. Photo: Didem Ambarlı. 


\section{Post-conference excursion}

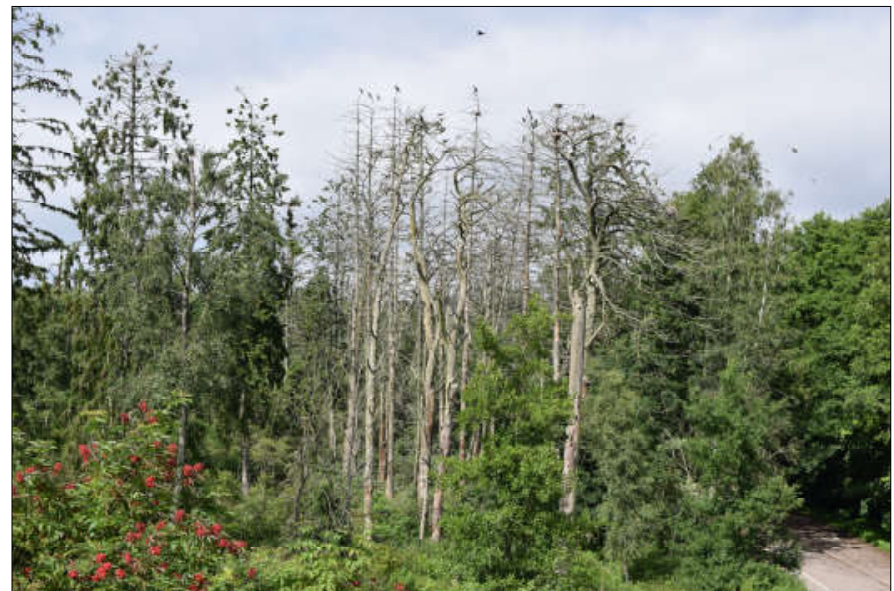

Dead pine trees in the area of cormorant colony. Photo: Solvita Rūsiṇa.

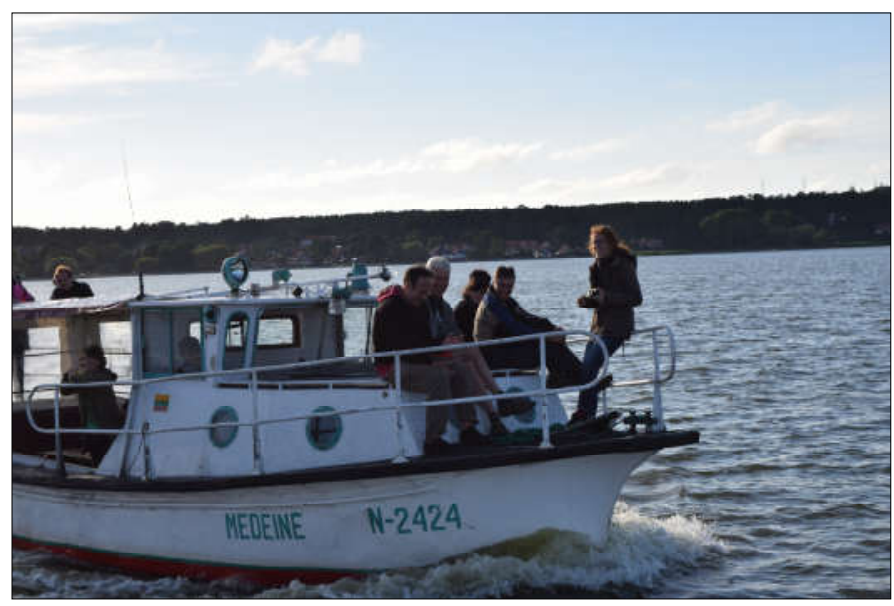

Crossing the Curonian Lagoon. Photo: Solvita Rüsina.

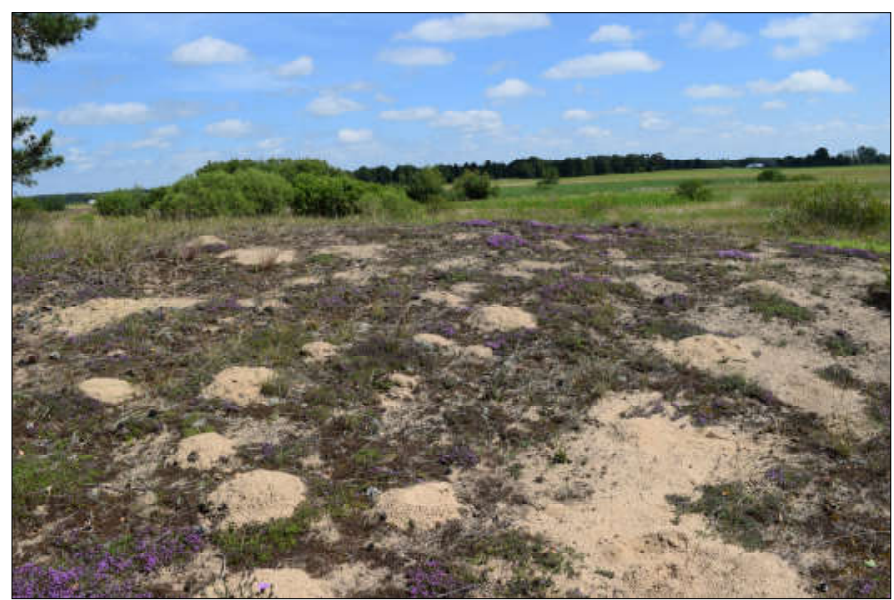

Inland dune in the Nemunas Delta. Photo: Solvita Rūsina.

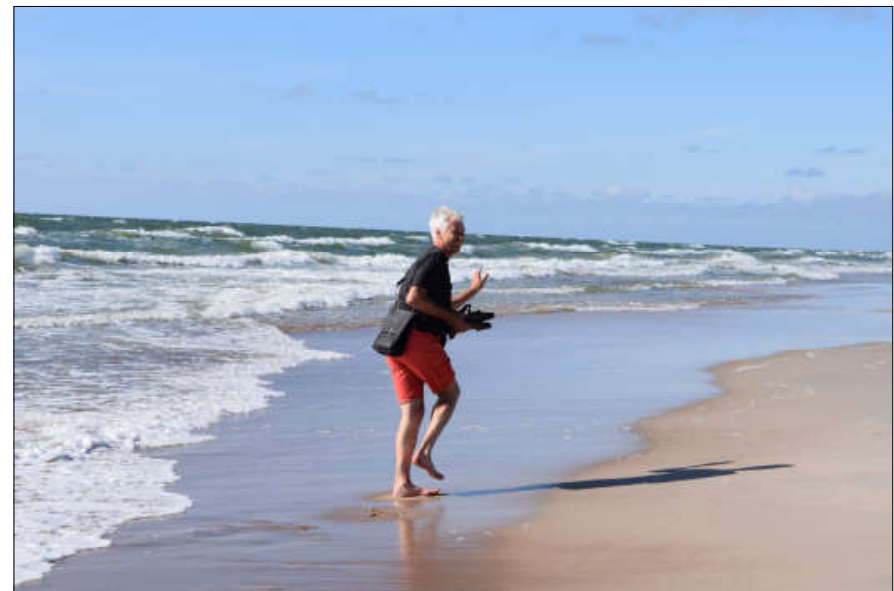

Enjoying the waters of the Baltic Sea. Photo: Solvita Rūsina.

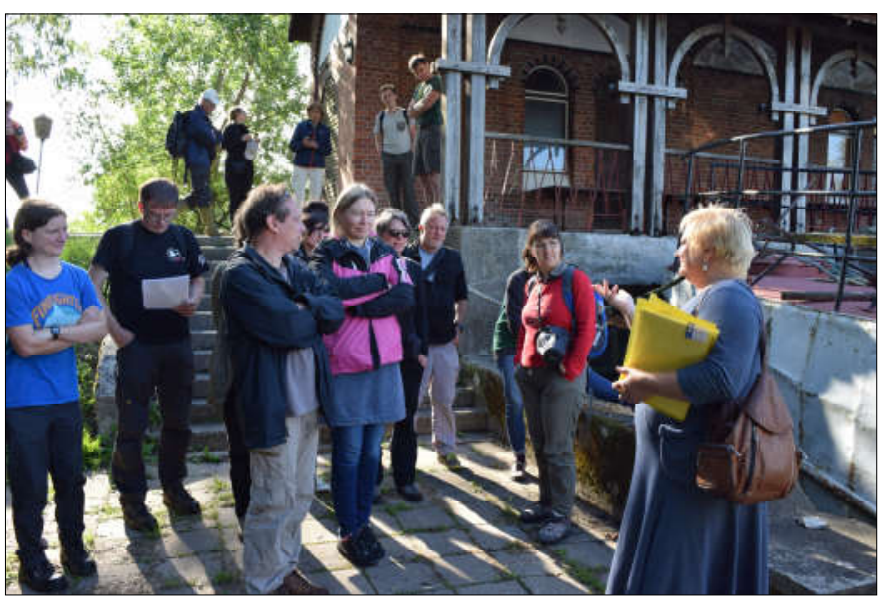

The oldest water-pumping station in the Uostadvaris. Photo: Solvita Rūsina.

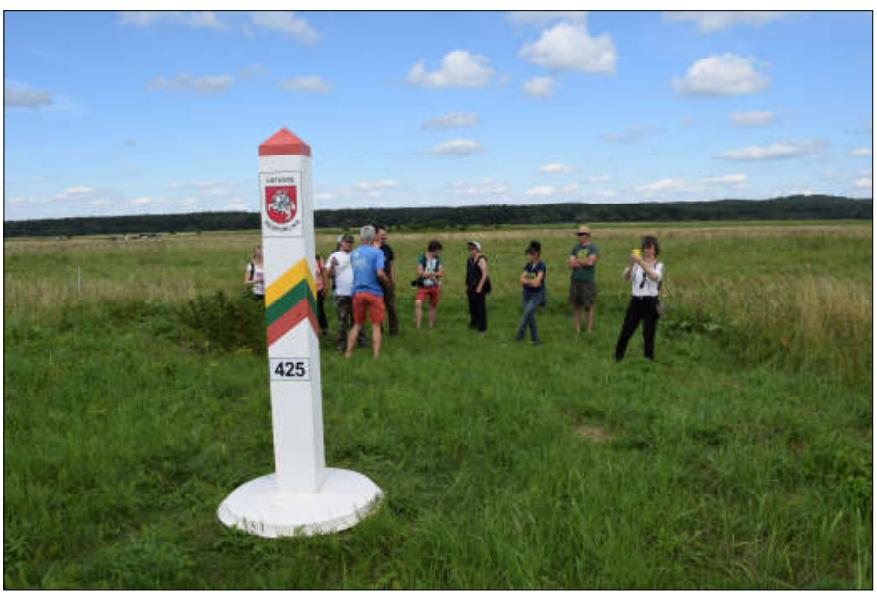

Lithuanian-Russian Federation border. Photo: Solvita Rūsina. 
The grassland party of the EDGG took place in Šlokenbeka manor ensemble - a rare sample of a medieval fortified manor in the Baltic States that has survived to the present day.

The Post-conference excursion took place on the Curonian Spit and the Nemunas River Valley in western Lithuania. Participants observed the diversity of the coastal sand vegetation (Ammophiletea, Koelerio-Corynephoretea) including sandy beaches, coastal foredune ridges, sea sand plain/palves, and the Great Dune Ridge, with shifting and fixed dunes and populations of Linaria loeselli - an endemic species to the eastern Baltic coast. The Nemunas - the largest Lithuanian river floodplains - offered the diversity of the floodplain vegetation including swamp and fen vegetation (Phragmito-Magnocaricetea), managed grasslands of different floodplain ecological belts (MolinioArrhenatheretea, Festuco-Brometea) and dry grasslands of riverine dunes (Koelerio-Corynephoretea).

We, the organizers, wish to thank everyone who helped us with suggestions and advice, and all the participants who were willing to share their ideas and to attend the conference. We gratefully acknowledge the contributions of several sponsors who made the organization of this conference possible. Finally, we thank the University of Latvia, Latvian Botanical Society, and the Nature Research Centre, Lithuania for hosting this event.

\section{References}

Rašomavičius, V., Dikšaitè, L., Sendžikaitè, J., Matulevičiūtè, D., Uogintas, D., Petrulaitis, L. \& Augutis, D. 2017. Semi-natural grasslands across borders. Post-conference excursion 9-11 July 2017, Western Lithuania. Vilnius, LT. http://www.edgg.org/pdf/ EGCabstracts/2017/Post Conference Excursion small.pdf

Rūsina S. (ed.) 2017a. 14th Eurasian Grassland Conference Seminatural Grasslands Across Borders. Book of Abstracts. 4-11 July 2017, Riga (Latvia) and Western Lithuania. University of Latvia, Riga, LV. http://www.edgg.org/pdf/EGCabstracts/2017/Book of Abstracts 14EGC.pdf

Rūsiṇa, S. (ed.) 2017b. Outstanding semi-natural grassland sites in Latvia: biodiversity, management, restoration. University of Latvia, Riga, LV. http://www.edgg.org/pdf/EGCabstracts/2017/ MidexcursionEGC2017.pdf

\section{Local organising committee:}

Solvita Rūsiṇa, Riga, Latvia, rusina@lu.lv Lauma Gustina, Riga, Latvia, lauma.gustina@lu.Iv

Rūta Sniedze-Kretalova, Riga, Latvia, ruta.sniedze@ldf.lv Valerijus Rašomavičius, Vilnus, Lithuania

valerijus.rasomavicius@botanika.It

Domas Uogintas, Vilnus, Lithuania,

domas.uogintas@botanika.It

Inese Silamikele, Riga, Latvia, inese.silamikele@lu.lv

EDGG Executive Committee:

Michael Vrahnakis, Karditsa, Greece, mvrahnak@teilar.gr

Didem Ambarlı, Düzce, Turkey, didem.ambarli@gmail.com

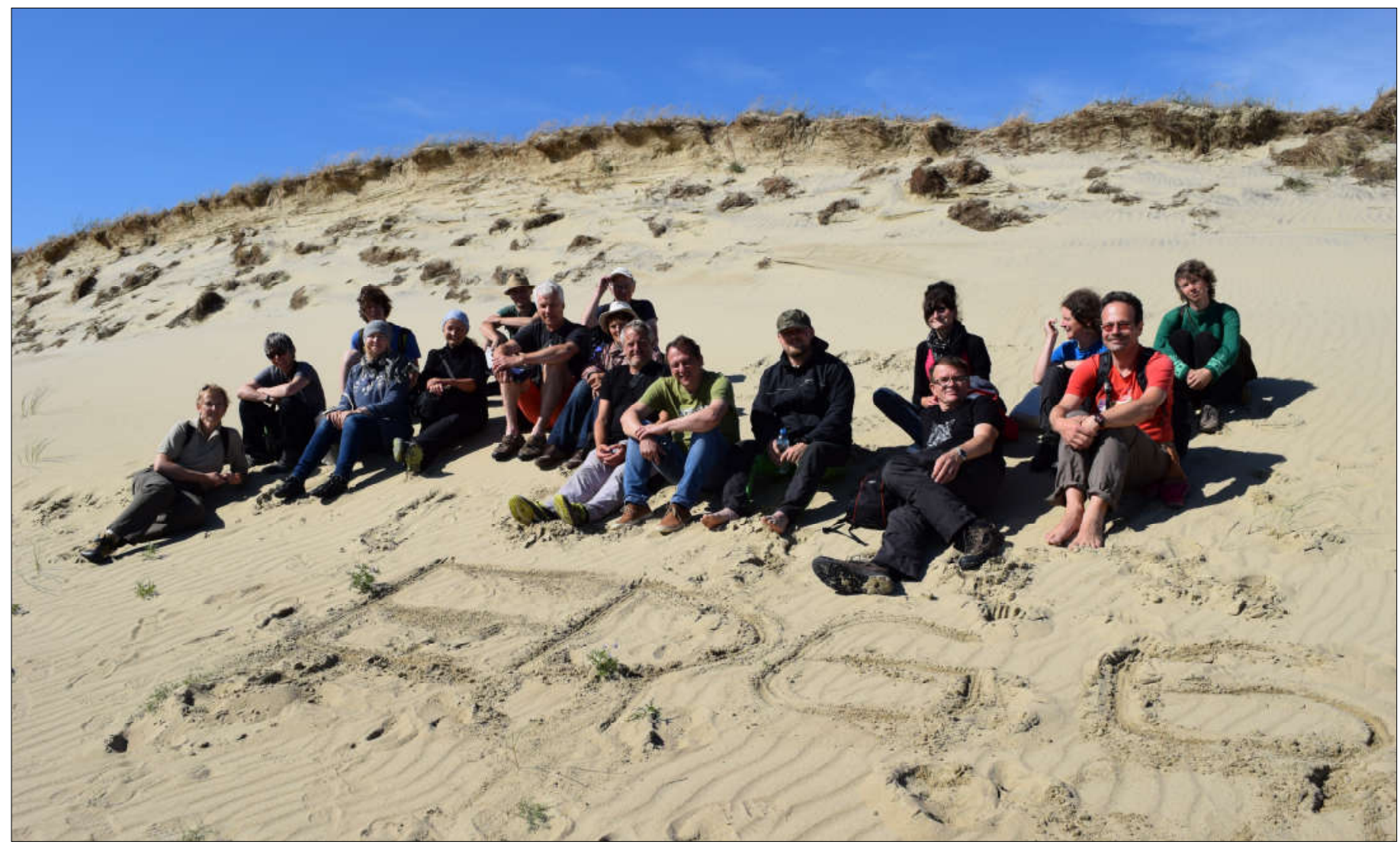

Participants of the post-conference excursion. Photo: Solvita Rūsiṇa. 


\section{Reports from IAVS grantees}

\section{Valentina Borodulina, Moscow, Russia}

My name is Valentina Borodulina and now I am a PhD student of Lomonosov Moscow State University (Biological Faculty; Department of Geobotany). The conference in Riga was my second EDGG conference (my first one was in Sighisoara, Romania). I am grateful to EDGG for the opportunity to participate in such conferences. It is a great experience for me: the experience of communication and the experience in preparing and presenting my own work to foreign colleagues. During the conference in Riga, I was able to communicate with scientists from other countries and to find common topics for discussion. The conference EGC 2017 seemed to be the perfect place to present our new results on classification of herbaceous vegetation in NW Russia where semi-natural grasslands play an important role. Herbaceous vegetation of NW Russia is poorly studied that is why it is very tempting for us to communicate with scientists from neighboring countries to compare our classification schemes. Besides, it was interesting to find comparison in ecological features of syntaxa revealed in NW Russia with the similar in Latvia. During the conference, I was able to get feedback on my study and recommendations for further researches. In addition, I learnt more about research on abandoned grasslands in other countries and exchanged policies on management, conservation and restoration with foreign scientists.

Another point was that I knew more from other young investigators about different study programs and the chance to exchange experience of using modern methods in dealing with data with other scientists.

In addition, during the conference we had wonderful excursions, where we saw a variety of Latvian grasslands. Unfortunately, I could not attend all the excursions, but those, which I have visited, were great.

I want to thank the organizers for the wonderful conference!

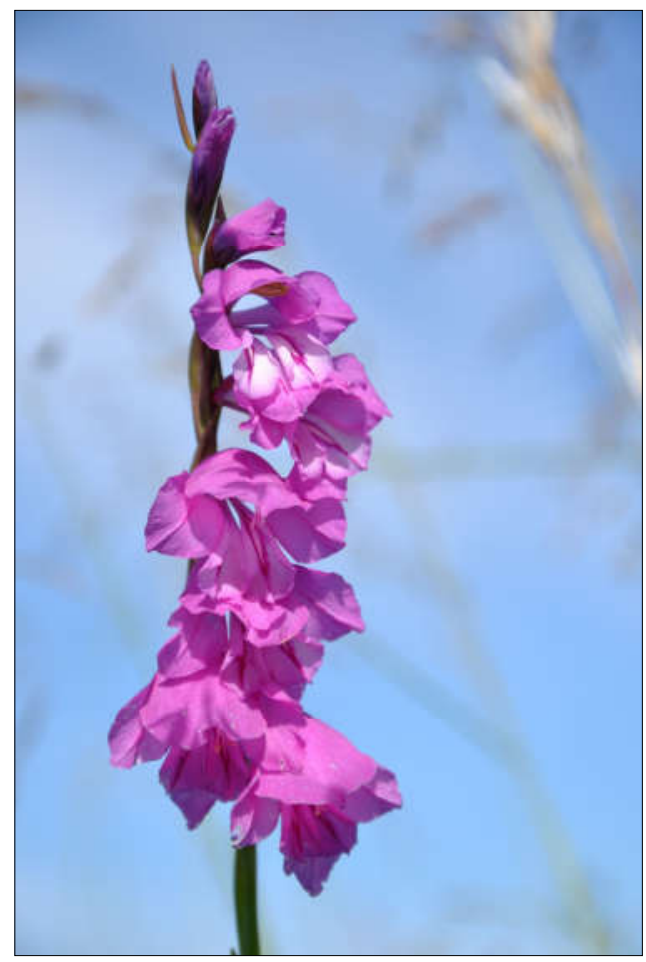

Gladiolus imbricatus from the mid-conference excursion. Photo: Anikó Csecserits.

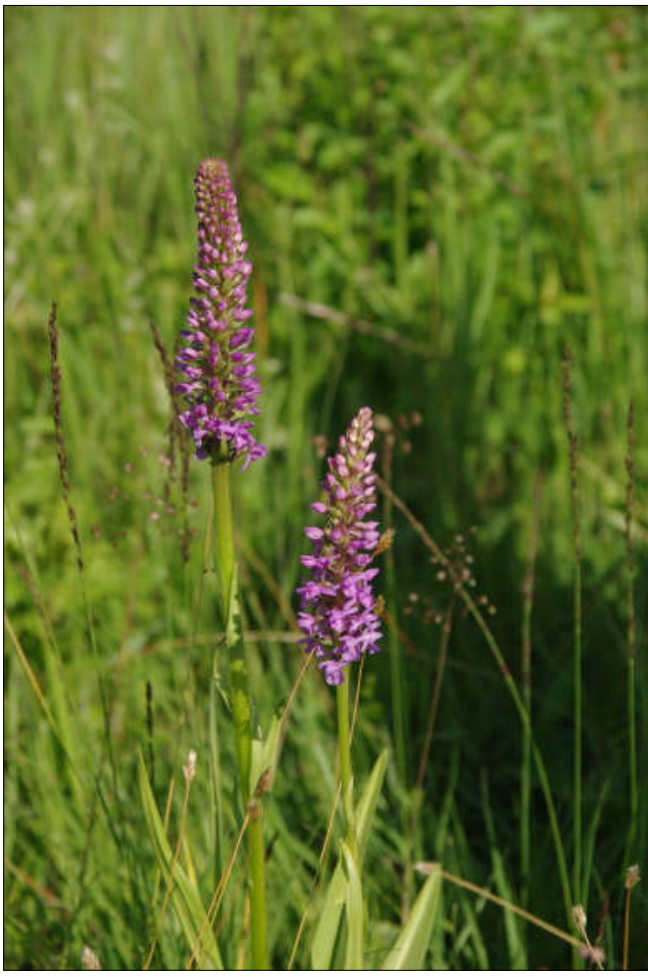

Gymnadenia conopsea from the mid-conference excursion. Photo: Valentina Borodulina.

\section{Anikó Csecserits, Vácrátót, Hungary}

First and foremost I would like to express my thanks for the IAVS and EDGG for the grant, which made me possible to participate on the 14th EGC in Riga, Latvia. It was a great experience for me! I looked forward very much for the conference of EDGG in Riga, as I know well, that EDGG conference used to be interesting, well -organized and beside still very familiar and friendly. And I was never before in any Baltic state.

There were many interesting presentations and posters about the present state and use of grasslands, about the problems of regulations and conservations, from which I liked very much those dealing with the phytogeography of grasslands. Moreover it was interesting to see, how different definitions exist for the "semi-natural", "permanent" or "extensive" grasslands. I thing, there should be made some unification regarding these terms, as they occur in the regulations of different countries. In addition it was interesting to see how important is everywhere the local adaptation and tradition in the management of grasslands. I thing, we should take care, document and keep it for the future. The other important and nice part of the EDGG conference are always the social events: field trips and grassland parties. In this case everything was excellent (there were even a beautiful and huge rainbow above the Daugava river- who organize this : )? I liked the experience during the field trips, how the species common in southern grasslands became rare or even endangered in the North e.g. Scabiosa ochroleuca or Koeleria cristata. The Latvian and Lithuanian landscape are beautiful and still well preserved. It was impressive, how many people are deeply involved in nature. From the many places we visited during the pre-, midand post-conference tours, I enjoyed the best the sea-shore at Curonian Spit. There was only one problem, that we had to leave it.

Thank you again very much! I hope, I could go back in the Baltic once again! 


\section{Nina Polchaninova, Kharkiv, Ukraine}

I am very thankful to the IAVS grant committee for the opportunity to participate in the $14^{\text {th }}$ EDGG conference. Riga met us with heavy rain, but then the principle organizers arranged somehow for good weather, thus we could enjoy sunny days during the mid-and post conference excursions. I was glad to see familiar faces and meet new colleagues. Zoologists are still in the minority at our meetings, but I really appreciate my communications with the botanists and other specialists because only our joint efforts will be successful in grassland conservation.

From the presentations, I learned a lot on the changes of traditional land use and their impact on grassland ecosystems in various European countries. We are facing similar problems, so I can apply the gained knowledge when developing management plans for the local conservation areas. Mid-and post conference excursions shown us a variety of grasslands in Latvia and Lithuania. Most of all I was stuck by the sand dunes on Curonian spit. They were so different from all the sandy habitats I had already seen and studied!

The conference was perfectly organized. For the participants, all went in one go, but l do understand that was the result of the hard work of the conference team.
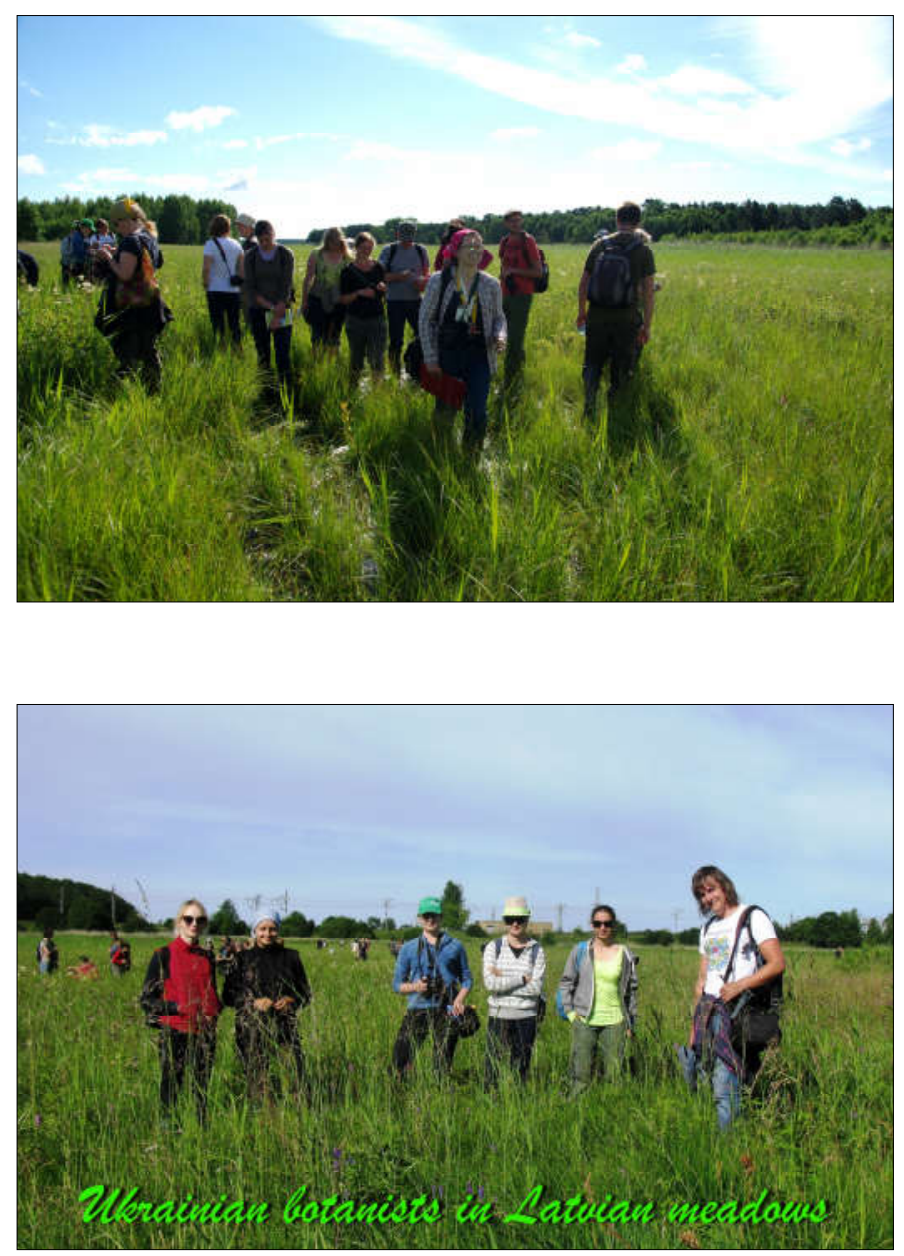

\section{Mid-conference excursion and participants from Ukraine. Photo: Nina Polchaninova.}

\section{Kateryna Norenko, Kyiv, Ukraine}

The conference itself was very useful for me, its topic "Semi natural grasslands across boarders" fully reflects my research interest, as I'm studying ecology and biology of an invasive species in semi-natural grasslands and wooded grasslands and its impact on vegetation.

In the sessions, the presentations of the most interest were those, which are related to ecosystem restoration, as I'm convinced that having applied side of science is essential to combat pressure of unfavorable factors that are so usual in modern conditions. I like such applied direction of meetings and I'd love to have more like this in the future. I liked how the poster session was organized, everybody had time to present his/her poster, and that was definitely better than "doing circles" and wondering from one poster to another without organized procedure. I didn't participate in the post -conference excrsion, but the mid-conference excursion was great.

Attached you can also find some pictures.

Many thanks for the organization, it was a big pleasure to participate!

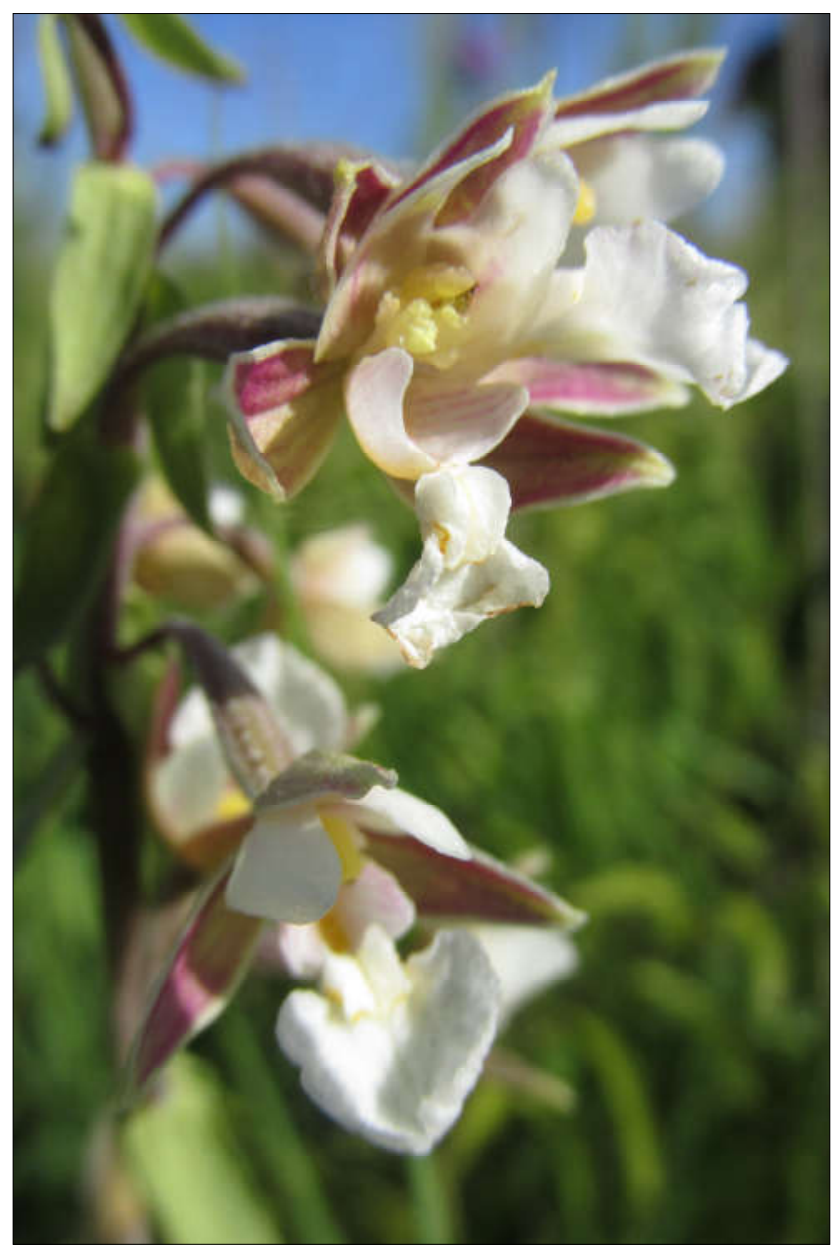

Epipactis palustris from the mid-conference excursion. Photo: Kateryna Norenko. 


\section{EDGG General Assembly 2017}

The General Assembly (GA) of the EDGG was held in Riga, Latvia, on $8^{\text {th }}$ July, at the end of the $14^{\text {th }}$ Eurasian Grassland Conference (EGC). This GA was not a Qualified GA, as it did not fulfil the criteria of being attended by at least 40 members from at least 10 different countries, with no country being represented by more than a third of those present (EDGG bylaw §5.4). This meant that we could present information and hold discussion but not make binding decisions. The Executive committee was represented by Didem Ambarlı, Monika Janišová, Anna Kuzemko, Péter Török, Mike Vrahnakis and Stephen Venn.

The Secretary-General opened the GA at 5:00 p.m. The first topic was the results of the 2017 EC election, in which there were eight candidates, of which seven were elected. Péter Török presented an overview of the EDGG finances, which showed a balance of $€ 1159$. Stephen Venn presented an overview of the membership development prepared by Idoia Biurrun, which showed that we have 1231 members from 67 countries as of May 2017. The greatest numbers are from Germany (278) and Greece (133). The report on the Eurasian Grassland Conferences (EGCs) was provided by Didem Ambarlı. A presentation was given by Sabina Burrascano on the proposed EGC 15, to be held on $5-8^{\text {th }}$ June 2018 in Sulmona, in Central Italy and organized by Sapienza University of Rome, Italian Botanical Society and National Park Majella. A comprehensive report on the Field Workshops was provided by Jürgen Dengler and Idoia Biurrun. This covered previous workshops, the 2017 FW from Central Italy and the proposed $11^{\text {th }}$ FW for summer 2018 in the Inner Valleys of Austria, which was presented in more detail by Martin Magnes. There is also a proposal for a FW in Armenia in 2019, to be organized by Alla Aleksanyan. Péter Török presented the status of EDGG publications, including material provided by Jürgen Dengler.
In addition to the various SIs and SFs, this included the Global grassland management book, edited by V. Squires, for which Jürgen is editing a section on Palaearctic grasslands, to which several EDGG members have contributed. Didem Ambarlıpresented the status of the EDGG homepage, which is maintained and updated, though we are initiating a project to reorganize it and will apply to the IAVS to support this project. Anna Kuzemko presented a review of the EDGG Bulletin. We produce four editions of the bulletin p.a. The format has changed somewhat during the previous year, and Anna has taken the role of Editor-in-Chief from Monika Janišová. The EDGG also has a Facebook group https://www.facebook.com/ groups/938367279561202/ that currently has 155 followers. The Policy Committee report, given by Mike Vrahnakis, informed us that 363 people have now signed the Smolenice Declaration of 2010. Other policy initiatives have been appeals to the Ukrainian government about afforestation of steppe sites in 2011 and disturbance to the Tarutyinski protected area in 2016. Monika Janišová provided a report of our current collaboration with IAVS, which includes support for travel grants to attend the EGC. The IAVS will hold its 60th annual symposium on the topic of "Natural Ecosystems as Benchmarks for Vegetation Science" at Montana State University on $23^{\text {rd }}-27^{\text {th }}$ July 2018 . There were no additional matters raised for discussion at the GA. At the end of the meeting, the EC expressed its gratitude to the organizers of the conference and awarded the prizes for the best young scientist poster and oral presentations.

\section{Stephen Venn, Secretary-General, Helsinki, Finland,} stephen.venn@helsinki.fi

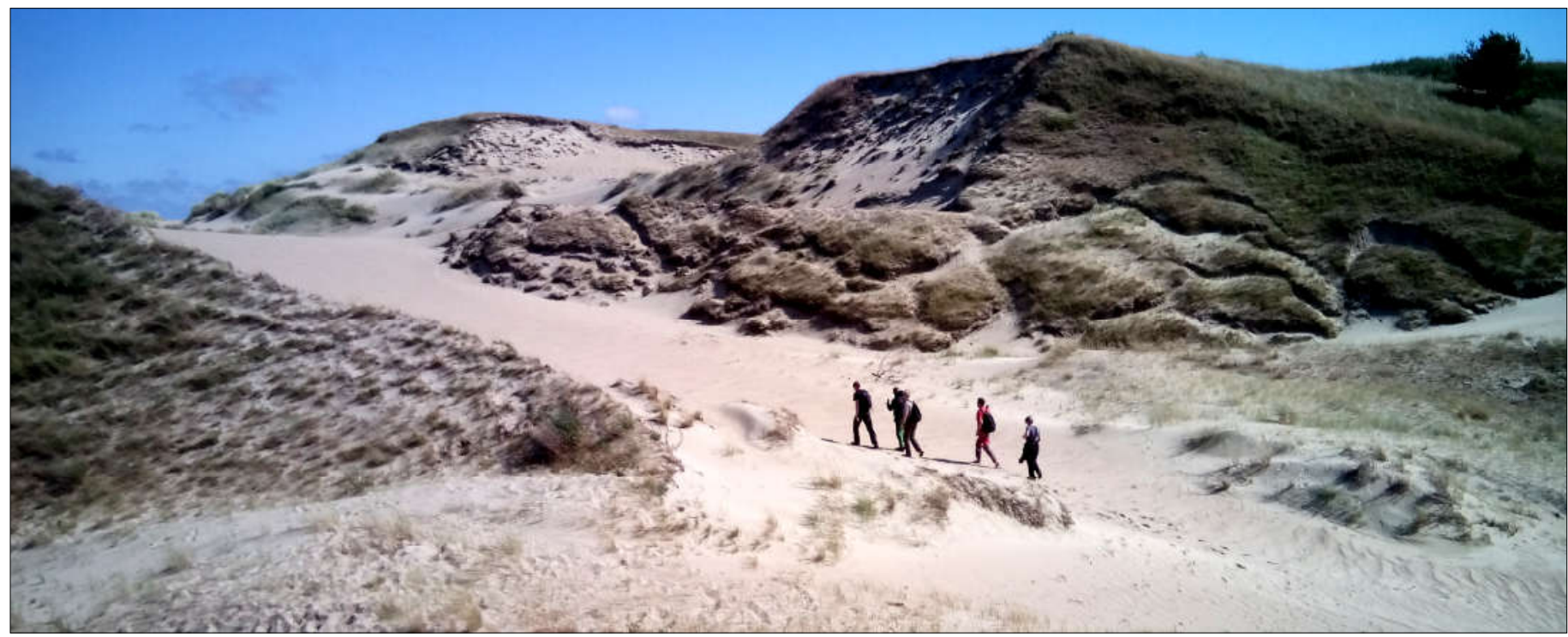

Participants of the EGC 2017 post-conference excursion, grey dunes at the Curonian Spit, Western Lithuania. Photo:

\section{A. Kuzemko.}




\section{Frontiers of grassland conservation and restoration - New Research Group established to link ecological theory with conservation}
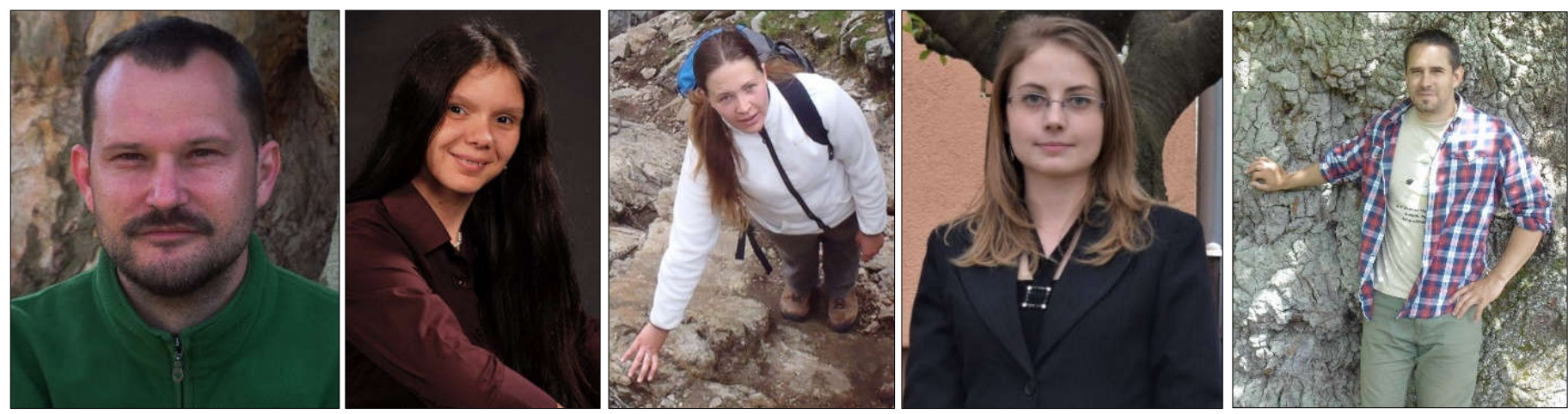

Fig. 1. Members of the research group (from the left to the right, Péter Török, Viktória B.-Béres, Judit Sonkoly, Edina Tóth and Csaba Tölgyesi).

Species-rich landscapes and semi-natural grasslands are facing large-scale degradation mostly caused by change in traditional land-use (Dengler et al. 2014; Wesche et al. 2016). The loss of biodiversity also strongly affects landscape functionality via decreased levels of pollination and biological pest control. Habitat restoration is a powerful tool to counteract degradation by the recovery of former species richness and area of natural habitats and by creating an habitat network and connectivity in landscapes dominated by human influence. Thus, habitat restoration has a top priority both in scientific research and in practice. There is a strong demand to seek cost-effective habitat management and recovery strategies, because of the high costs of technical restoration. Incorporating findings of theoretical ecology into practical restoration can address this need (Török \& Helm 2017). To support theory driven restoration research with the financial support of the Hungarian Academy of Sciences, a new research group was founded at the University of Debrecen, led by one of the EDGG Chairs, Péter Török.

The support of the research group is granted for five years with a total budget of 650000 Euros. The team consists of five young researchers recruited from various fields of vegetation and ecosystem ecology (Group members listed in Fig. 1). The goal of the research group is to develop and test ways to link biodiversity conservation, sustainable management and restoration in order to meet the major challenges related to altered land use and climate change.

The research group is seeking for scientific collaboration from the whole Palaearctic in the following particular topics of conservation and restoration of grassland ecosystems: (i) Effects of traditional management by grazing and mowing on species and trait composition of grassland vegetation; (ii) Effects of management and fragmentation on soil seed banks and dis- persal in agricultural landscapes; (iii) Relationship of specific seed traits, seed bank development and dispersal in grasslands (iv) Restoration and post-restoration measures to increase biodiversity.

The research group, in close cooperation with the MTA-DE Biodiversity and Ecosystem Services Research Group, also facilitates the submission of applications for full degree doctoral studies from developing countries for Stipendium Hungaricum. In case of a successful application, the group supports applicants to complete their doctoral thesis in one the above mentioned topics or any other topics related to biodiversity research and/or ecosystem services.

\section{References}

Dengler, J., Janišová, M., Török, P. \& Wellstein, C. 2014. Biodiversity of Palaearctic grasslands: a synthesis. Agriculture, Ecosystems \& Environment 182: 1-14.

Török, P. \& Helm, A. 2017. Ecological theory provides strong support for habitat restoration. Biological Conservation 206: 85-91.

Wesche, K., Ambarli, D., Kamp, J., Török, P., Treiber, J. \& Dengler, J. 2016. The Palaearctic steppe biome: a new synthesis. Biodiversity and Conservation 25: 2197-2231.

\section{Research group contacts}

Péter Török, Debrecen, Hungary, molinia@gmail.com

Judit Sonkoly, Debrecen, Hungary,

judit.sonkoly@gmail.com

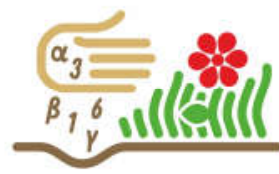

MTA-DE Lendület

Functional and Restoration Ecology Research Group 


\section{Short contribution}

\section{The Steppe Day was commemorated in Ukraine for the first time}

An event special for every ecologist took place at the end of May in the Donetsk region. "Kamyany mohyly" ("Stone graves") celebrates its $90^{\text {th }}$ birthday. The 1927 Mariupol District Executive Committee issued a decree which declared this "highland in the midst of the steppe" to be a nature reserve. For more than a half of the century, "Kamyany mohyly" has been a division of Ukrainian steppe nature reserve. The same year, the famous botanist Mykhaylo Klokov foresaw the future of the reserve: "... apparently, even literature will be created around "Kamyany mohyly"..." (Klokov 1927). The scientist was right and it seems that the largest number of research papers about reserves in Ukraine is namely dedicated to "Kamyany mohyly". The bibliographical list contains around 1500 publications while only a collection of research papers of the jubilee conference as well as other publications of 2017 add to this list at least several dozens of articles and scientific works (Hramma \& Sirenko 2012; Yarovyy \& Podpryatok 2016).

Despite its small area (399 ha), the nature reserve contains 500 plant species, a few dozen of which are protected and two of which are local endemics and occur only here. Although there are dozens of kilometres of agricultural land around the nature reserve, cranes and other rare species of birds come here to nest. In addition to this, more than 3000 species of insects occur in this area.

On the anniversary of the patriarch among research areas, a scientific conference took place that brought together about half a hundred participants in front-line Pryazovia. Neither the echo of heavy explosions, roads broken by tank tracks, nor living in soldiers' tents hampered the scientists in get- ting to the conference. Unfortunately, neighbouring divisions of Ukrainian steppe nature reserve "Homutovskyi step" and "Kalmiuske" belong to the occupied territories now. The war did a lot of harm to the latter one.

At the initiative of Victor Sirenko, the Chief of Department of Ukrainian steppe nature reserve "Kamyany mohyly", the conference has become a much more important event than an ordinary anniversary celebration. It was the event that established the holding Steppe Day in Ukraine (Sirenko et al. 2017b). Such a celebration is of great importance because the steppe is a natural environment that may conjure up a new ecological image of Ukraine in Europe. It's high time to do that since residents of other countries associate the ecology of Ukraine with Chernobyl disaster. The virgin soils occupy nowadays small areas because of being ploughed up during the $19-20^{\text {th }}$ centuries. Their remnants with various plant and animal species occur as isolated lands in the forest-steppe and steppe zones on the slopes of creeks, ravines, river valleys, and on the rocky outcrops. The steppe zone in Ukraine occupies about 40 per cent of the total area and only 4-4.5 per cent of that area has not been ploughed up and support natural and transformed steppes (Sirenko et al. 2017a). The existence of rare species of plants and animals that are included in the Red Book of Ukraine makes this area so unique. By the way, one third of such species is a representative of the steppe flora or fauna (Vasyliuk et al. 2010). But the majority of Slavs mentally associate the steppe with scrubland, wideness, but never with an extremely important biome of global importance and one of the richest ecosystems on the Earth (Anon. 2006).

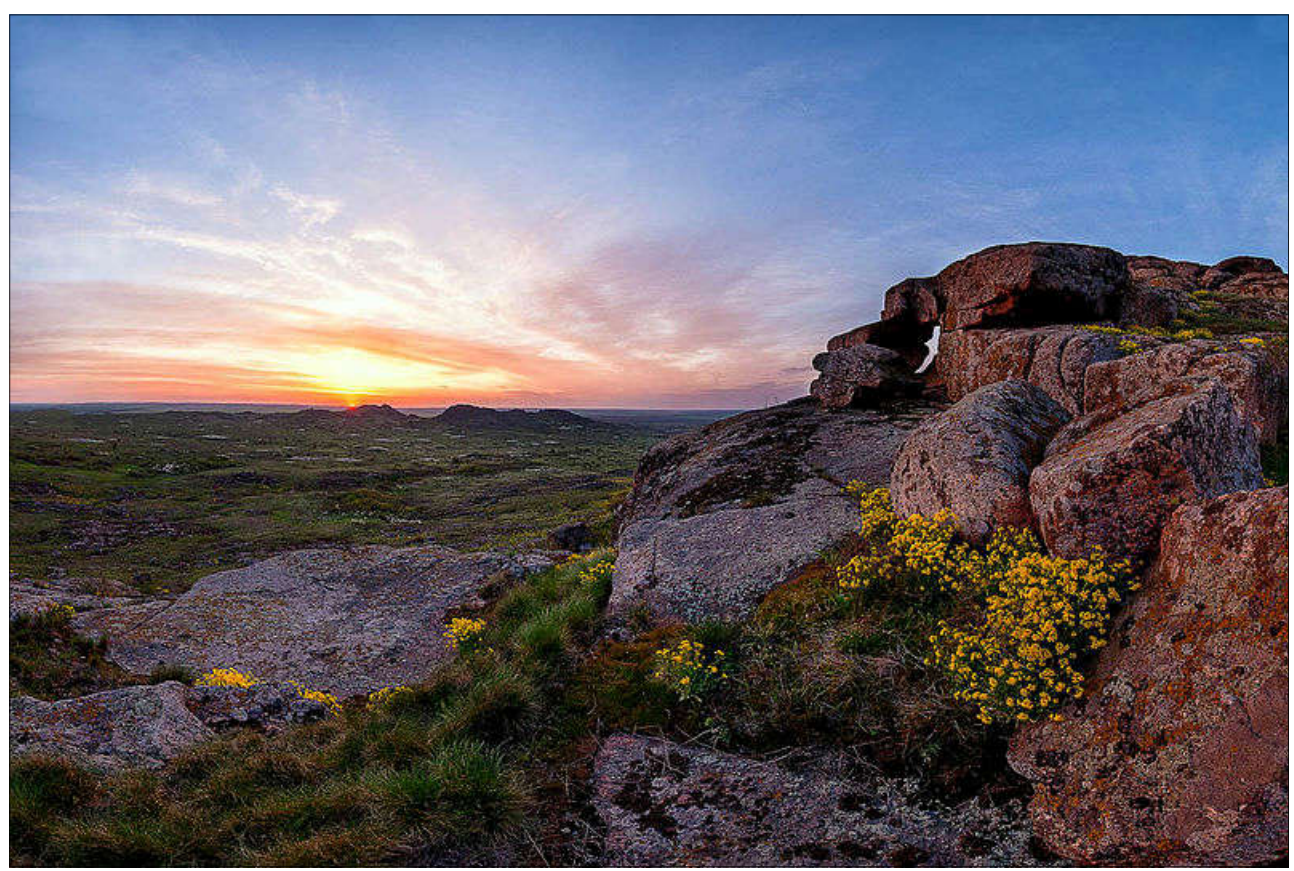


The first Steppe Day included not only a scientific conference but also a range of learning, environmental and culturalrelated activities. Thus, an 80-man camp of ecologists worked for four days on the lakeshore at the border of the nature reserve, also a survey expedition of two steppe lands for reservation and an ethno-cultural festival "The Wild Fields - a way to Europe" took place there.

The programme of the festival included a morning prayer for the soldiers who died in 1223 in the Battle of the Kalka River; quizzes on the steppe theme; exhibitions of the art and historical museum and expositions of folk craftsmen; reconstruction of historical camps of the Scythian epoch; the Princes epoch; the Cossacks epoch; performance of "the Scythians" in fencing and Scythian archery, Cossack hand-tohand fighting and "Kladynets" gymnastics; fancy riding of Cossack cavalry, knight tournaments and so on. It's hard to diminish the inspiring role of the festival for the inhabitants of the heavily populated front-line regions. The officials of different levels and a few thousand of locals have visited the festival.

Steppe Day is planned to be held each year from the last week of May to the first week of June.

Acknowledgement: We are very grateful for Catherine Ryabovol for translating the text into English.

\section{References}

Anon. 2006. Strategiya sohraneniya stepey Rossii: pozitsiya nepravitelstvennyih organizatsiy. Izd-vo Tsentra ohranyi dikoy prirodyi, Moscow, RU.

Hramma, V.M. \& Sirenko, V.O. 2012. Zapovidnyk "Kam"yani mohyly": bibliohrafichnyy pokazhchyk literatury (1883-2012 rr.). Vid-nya Ukr. step. pryrod. zapovidnyka NAN Ukrayiny "Kam"yani mohyly". Dyvosvit, Poltava, UA.

Klokov, M. 1927. Kam"yani mohyly. (Zahal'nyy nacherk roslynnosty). Okhorona pam"yatok pryrody na Ukrayini 1: 34-39.

Sirenko, V.O., Bayrak, O.M. \& Vasylyuk, O.V. 2017a. Perspektyvni formy pryrodookhoronnoyi propahandy zberezhennya stepiv. Conservation Biology in Ukraine 2 (1): 211-213.

Sirenko, V.O., Bayrak, O.M., Vasylyuk, O.V. \& Sirenko, N.M. 2017b. Naukovo-orhanizatsiyni zasady pryrodookhoronnoho forumu «Den' Stepu». Pryrodna ta istoryko-kul'turna spadshchyna rayonu zapovidnyka "Kam"yani Mohyly». Conservation Biology in Ukraine 4: 322-326.

Vasilyuk, A.V., Parnikoza, I.Yu. \& Shevchenko, M.S. 2010. Bioraznoobrazie stepey pod ohranoy Krasnoy i Zelenoy knig Ukrainyi. Stepnoy byulleten 29: 33-36.

Yarovyy, S.S. \& Podpryatok, O.O. 2016. Ukrayins'kyy stepovyy pryrodnyy zapovidnyk NAN Ukrayiny: bibliohrafichnyy pokazhchyk literatury. Bil'mak, UA.

Oleksiy Vasylyuk, Vasylkiv, Ukraine, vasyliuk@gmail.com,

Oleksandr Sirenko, Nazarivka, Ukraine

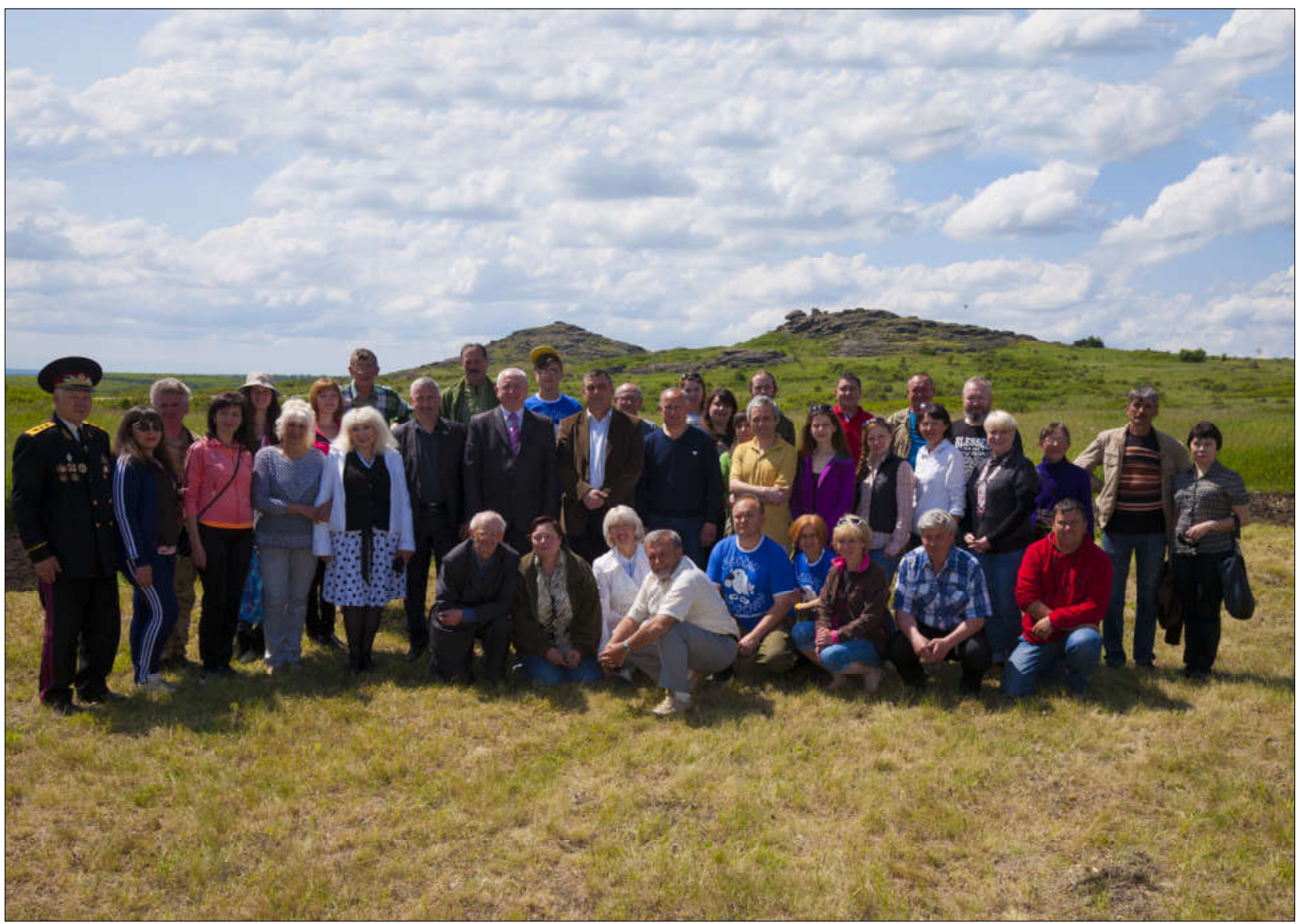

Participants of the Steppe Day. Photo provided by Oleksandr Sirenko. 


\section{Short contribution}

\section{A new potentially invasive grass, sand dropseed (Sporobolus cryptandrus) discovered in sandy areas of Hungary - A call for information on new localities}

In 2016, a new grass species was detected in urban areas of Debrecen (Nyírség region), and in a degraded grassland surrounded by forests patches, croplands and relatively undisturbed grasslands near Kiskunhalas (Kiskunság region). The species is a member of dropseed (Sporobolus) genus, identified as S. cryptandrus (Torr.) A. Gray (Sand dropseed). The Sporobolus genus consists of more than 160 species, out of which only two species are native in Europe (Hansen 1980; Peterson et al. 2010; Király \& Hohla 2015). The species we found, $S$. cryptandrus, has a native area of distribution in North-America including the United States, Canada and Mexico (Holub \& Jehlík 1987; Nobis et al. 2015). In its native range, it grows on disturbed sites mostly on sandy soils, riverbeds, rocky slopes and along roadsides, but it occurs also in short-grass prairies and chaparral communities and also rarely in sagebrush steppes (Tilley et al. 2009).

Outside of its native range, it has been reported from New Zealand, from several locations in Europe (Austria, Italy, the British Isles, France, Germany, the Netherlands, Slovakia, Spain and Switzerland), and from Russia (Volgograd) (Holub \& Jehlík 1987; Nobis et al. 2015 and citations therein). Formerly, other adventive Sporobolus species were reported from Hungary (Király \& Hohla 2015; Király 2016) and the newly found species was also reported from the western part of the country (= S. subinclusus -Historical data near the city of Györ discovered in 1924 and reported in Polgár 1933).

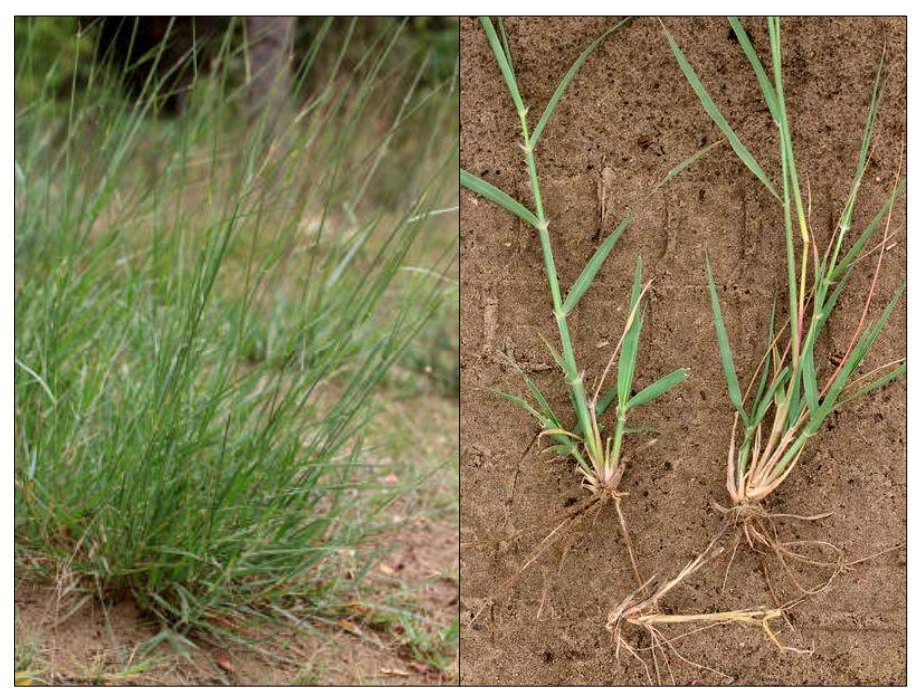

Fig. 1. Habitus and root system of Sporobolus cryptandrus Photo by the authors.
The species is an unimpressive perennial C4 bunchgrass with a height of $40-80 \mathrm{~cm}$ (up to $100 \mathrm{~cm}$ with inflorescences, Fig. 1). The auricula and ligula are very short (almost nothing) and at the orifice of the sheaths, on the leaves around the nodes there is a collar with dense white hairs (Fig. 2). The

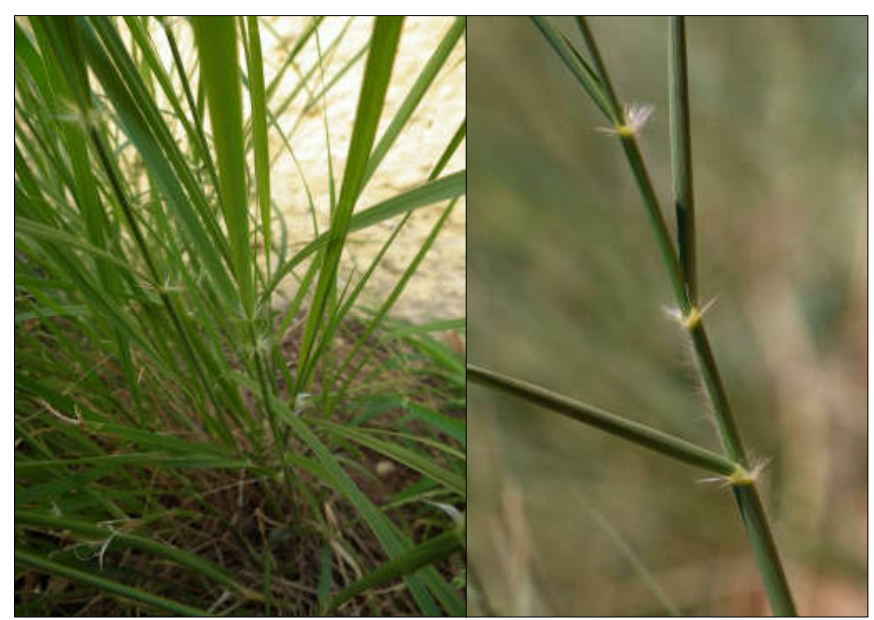

Fig. 2. White collar of hairs on the sprouts of Sporobolus cryptandrus. Photo by the authors.

breadth of leaves is around 4-5 $\mathrm{mm}$, sparse hairiness is typical also along the whole leaf edge. The edge of the leaves is sharp, but the leaves are softer than the leaves of a Calamagrostis. The inflorescences are very similar to that of an Agrostis, but they rarely completely open and are at least partly covered by its leaves (Fig. 3). There are other Sporobolus species, like $S$. contractus, S. compositus, S. flexuosus, or $S$. domingensis, which are quite similar to $S$. cryptandrus at a first glance. Thus, in each case a detailed identification procedure using also herbarium specimens may be necessary.

The areas where the species has been detected are covered either by acidic (Nyírség region) or calcareous sand (Kiskunság region), and both can be considered as disturbed, dry to semi -dry. In the location of the Kinskunság region the species also established in relatively undisturbed sandy grasslands. As the species is considered to be one of the most drought resistant species in short-grass prairie (see Tilley et al. 2009), further potential occurrences and its dispersal can be forecasted in dry sand regions or degraded rocky habitats of Europe.

Any information on new localities or on the Eurasian distribution of the species and/or the genus Sporobolus would be greatly appreciated by the authors! 


\section{References}

Hansen, A. 1980. Sporobolus R. Br. In: Tutin, T.G., Heywood, V.H., Burges, N.A., Moore, D.M., Valentine, D.H., Walters, S.M. \& Webb, D.A. (eds.) Flora Europaea. Vol. 5. pp. 257-258. Cambridge University Press, Cambridge, UK.

Holub, J. \& Jehlík, V. 1987. Sprobolus cryptandrus v Československu [Sprobolus cryptandrus found in Czechoslovakia]. Preslia 59: 117134.

Király, G. 2016. An invader at the edge of the world: Sporobolus neglectus (Poaceae) discovered at a remote locality in Hungary. Studia Botanica Hungarica 47: 335-344.

Király, G. \& Hohla, M. 2015. New stage of the invasion: Sporobolus vaginiflorus (Poaceae) reached Hungary. Studia Botanica Hungarica 46: 149-155.

Nobis, N., Ebel, A.L., Nowak, A., Paszko, B., Bobrov, A.A., Kotukhov, Y.A., Kupriyanov, A.N., Nobis, A., Zalewska-Gałosz, J., (...) \& Pliszko, A. 2015. Contribution to the flora of Asian and European countries: new national and regional vascular plant records, 4. Acta Botanica Gallica 162: 301-316.

Peterson, P.M., Hatch, S.L. \& Weakley, A.S. 2007. Sporobolus R. Br. In: Barkworth, M.E., Anderton, L.A., Capels, K.M., Long, S. \& Piep, M.B. (eds.) Manual of grasses for North America, pp. 212-217. Intermountain Herbarium and Utah State University Press, Logan, Utah, US.

Polgár, S. 1933. Neue Beiträge zur Adventivflora von Győr (Westungarn) IV. - Új adatok Győr adventív flórájához IV. Magyar Botanikai Lapok (Ungarische Botanische Blätter) 32: 71-77.

Tilley, D., St. John, L. \& Ogle, D. 2009. Plant guide for sand dropseed (Sporobolus cryptandrus). USDA-Natural Resources Conservation Service, Idaho Plant Materials Center, Aberdeen, Idaho, US.

Péter Török, Debrecen, Hungary, molinia@gmail.com Eszter Aradi, Kecskemét, Hungary, aradie@knp.hu

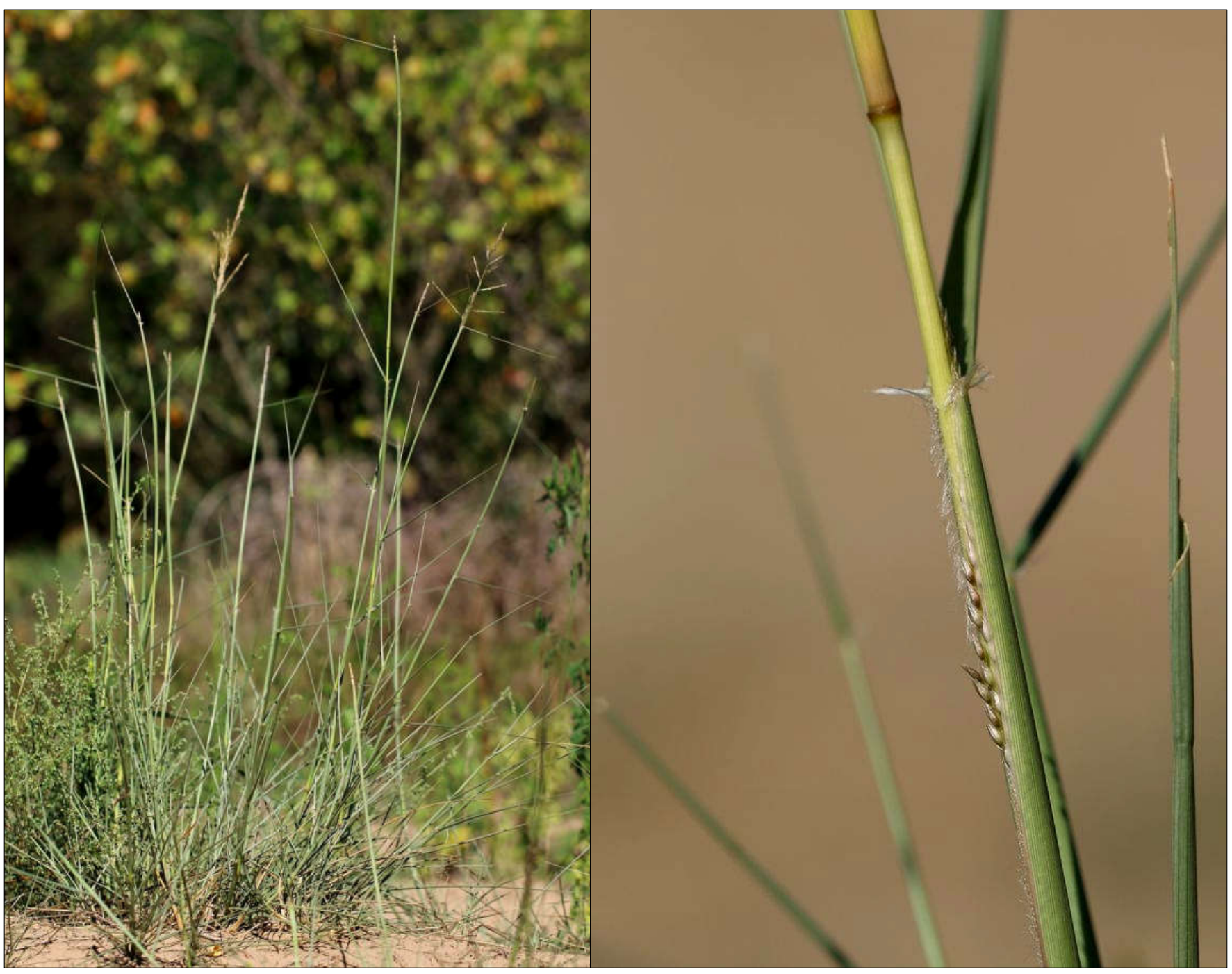

Fig. 3. Inflorescences of Sporobolus cryptandrus from a distance and in closer look. Photo by the authors. 


\section{Short contribution}

\section{Video clips about steppe national parks of Ukraine}

A series of video clips about steppe national parks has been filmed in Ukraine. The "first season" of the series introduces the national parks of the coastal zone of Ukraine. Here, along the shores of the Black and Azov Seas, lay the largest steppe national parks in Ukraine - Dzharylgatsky, Pryazovsky and Meotyda. The filming was made possible thanks to the project "Conservation of the Biodiversity of the Steppe Landscapes of the Seaside National Parks of Ukraine", which was supported by the Small Grants Program of the Global Environment Facility (GEF) and the United Nations Development Program (UNDP).

During 2016-2017, the work on filming was led by the creative group "B Wild", which brought together biologists, photographers and operators. The group plans to show littleknown nature territories to Ukrainian and, moreover, to foreign audiences. Traditionally, steppes are not a popular topic for Ukrainians. Therefore, most viewers will see in the videos for the first time the unique steppe and coastal landscapes. In all cases, the clips became the first video works of each of the national parks. The sequences were shot in different seasons, using techniques such as aerial photography and accelerated shooting. However, the most important thing in the creation of wildlife videos is that most members of the group are biologists who know where and when to look for rare animals, how to unobtrusively approach them, how to recognize rare endemic plants, and finally how to survive under difficult conditions of the hot coastal steppe.

All clips for "Season 1" can be viewed at https://goo.gl/C1Dpyo. Given the diversity of landscapes and the significant area of the National Nature Park "Meotyda", the cycle includes three video works on it. Currently, the creative group "B Wild" is working on filming the videos about further nature conservation areas of the steppe zone of Ukraine.

Oleksiy Vasylyuk, Vasylkiv, Ukraine, vasyliuk@gmail.com, Dariia Shyriaieva, Kyiv, Ukraine, darshyr@gmail.com

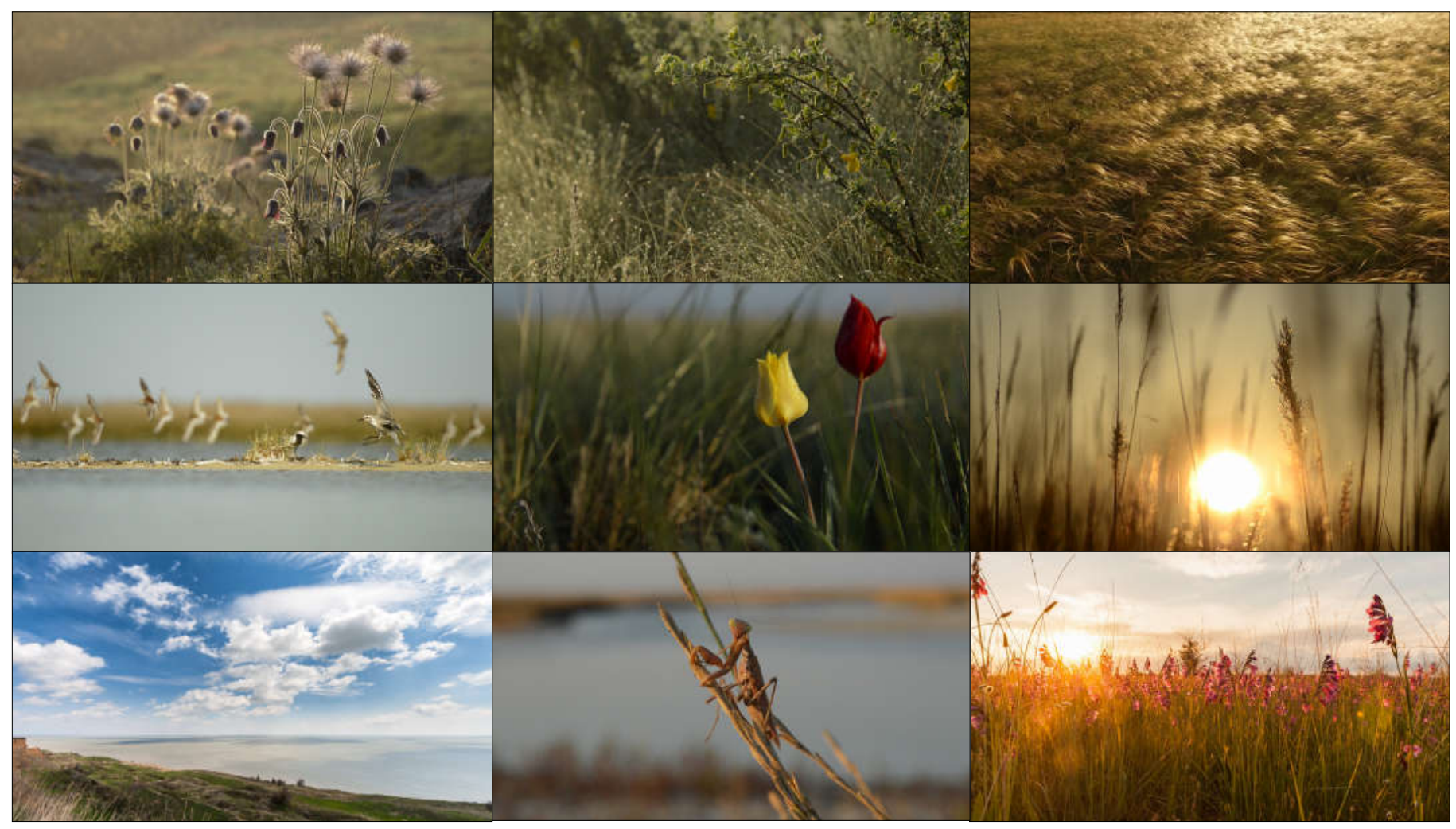

Screens from the video clips about steppe national parks of Ukraine. Photos: "B Wild". 


\section{Short contribution}

\section{Vascular Plants Checklist of Greece}

With this text we wish to inform you about the new website Flora of Greece web: http://portal.cybertaxonomy.org/floragreece/intro.

Through this website, the printed version of the Vascular Plants of Greece Checklist (Dimopoulos et al. 2013) and its Supplement (Dimopoulos et al. 2016) are made freely available. In this first version of the Flora of Greece web, under the EDIT platform (June 2017), taxonomic and floristic novelties published after October 2013 are not considered; however, this new information will be considered and uploaded gradually. The information published from November 2013 to October 2016 and from November 2016 to October 2017 will be uploaded in September and December 2017, respectively. Special effort has gone into making this website equally accessible and usable via mobile devices (smartphones and tablets), so that it can be accessed from everywhere (as long as you have internet access). This electronic tool represents an intermediate stage in the implementation of the recently launched project The Flora of Greece. Please read the "contribute" link in the menu, and don't hesitate to provide the scientific team of the Flora of Greece web with new data on floristic records for Greece or specific regions, as well as with photographs following the given guidelines.

The strength and potential to improve data quality and quantity in the Flora of Greece web originate from all of you.

Thank you in advance for your contribution.

\section{References}

Dimopoulos, P., Raus, Th., Bergmeier, E., Constantinidis, Th., latrou, G., Kokkini, S., Strid, A. \& Tzanoudakis, D. 2013. Vascular plants of Greece: An annotated checklist. - Berlin: Botanic Garden and Botanical Museum Berlin-Dahlem; Athens: Hellenic Botanical Society. Englera 31.

Dimopoulos, P., Raus, Th., Bergmeier, E., Constantinidis, Th., latrou, G., Kokkini, S., Strid, A. \& Tzanoudakis, D. 2016. Vascular plants of Greece: An annotated checklist. Supplement. Willdenowia 46: 301-347.

\section{Michael Vrahnakis, Karditsa, Greece,} mvrahnak@teilar.gr

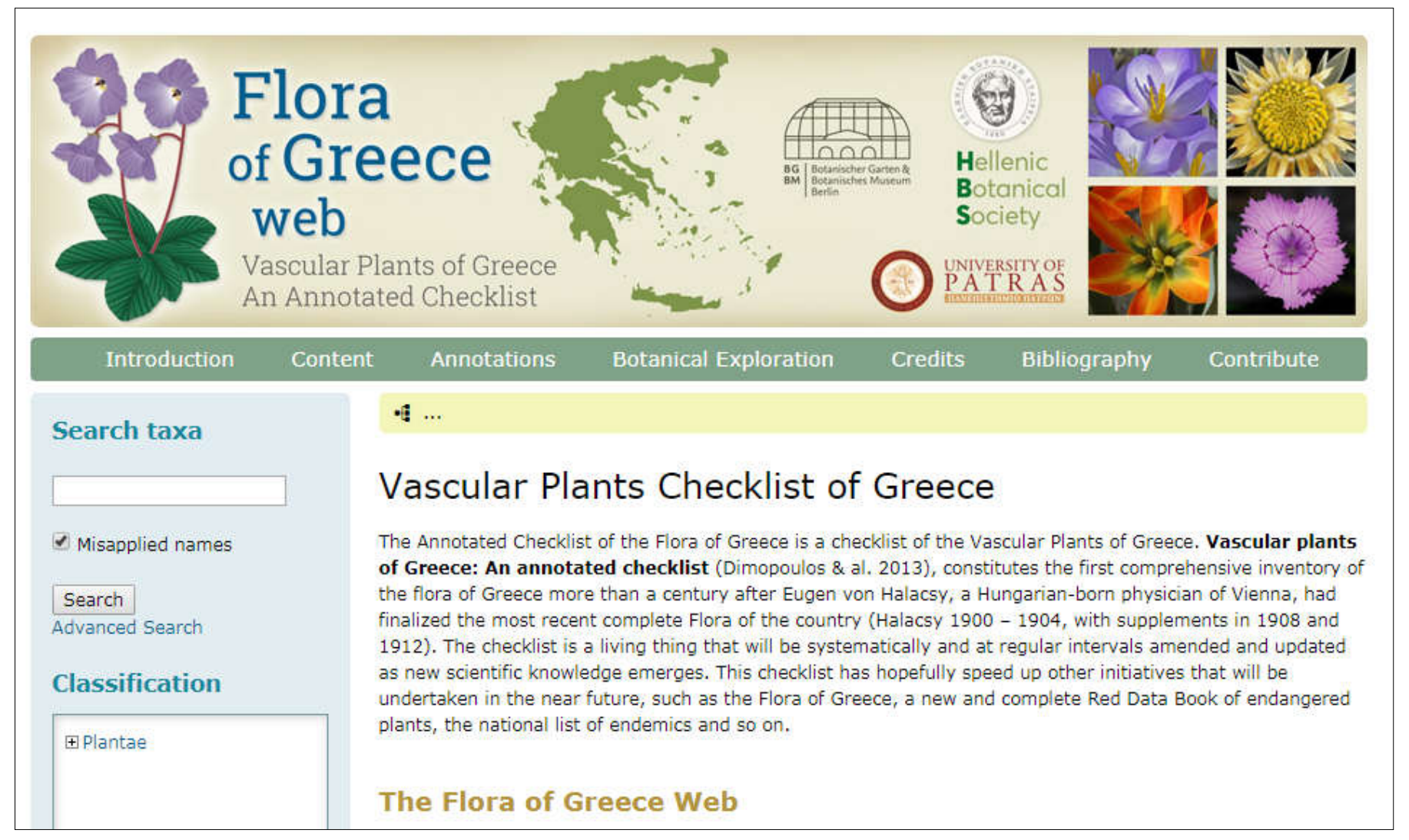




\section{Vegetation and conservation of Central-European grasslands - $12^{\text {th }}$ EDGG Special Feature in Tuexenia}

The $12^{\text {th }}$ EDGG Special Feature in Tuexenia continues the series of special features devoted to Eurasian steppes and seminatural grasslands. It focuses on the conservation, management and biodiversity of semi-natural and natural grasslands in Central Europe. This special feature was edited by Thomas Becker, Balázs Deák, Anikó Csecserits and Viktoria Wagner (Deák et al. 2017). Altogether 41 authors from six countries (Denmark, Germany, Hungary, Italy, Serbia and Switzerland) contributed to the published papers.

The paper of Gilhaus et al. (2017) deals with the effects of grazing and mowing and their interactions with environmental factors on grassland diversity. Kelemen et al. (2017) revealed the facilitative effects of shrubs on vascular plant species in grazed meadow-steppes. Szabó et al. (2017) studied the environmental characteristics and species composition of a sandy grassland habitat dominated by the newly discovered Festuca pseudovaginata. Čavlović et al. (2017) assessed the effects of climate change on protected grasslands in Serbia. Dengler et al. (2017) introduced the new collaborative vegetation-plot database GrassVeg.DE.

The publications are open access, and freely available at the homepages of Tuexenia and EDGG (http://www.edgg.org/ edgg_publications.htm).

\section{References}

Čavlović, D., Beloica, J., Obratov-Petković, D., Đurđević, V. \& Košanin, O. 2017. Simulation of long-term changes in environmental factors and grassland composition in three protected areas of Serbia. Tuexenia 37: 431-446.

Deák, B., Wagner, V., Csecserits, A. \& Becker, T. 2017. Vegetation and conservation of Central-European grasslands - Editorial to the 12th EDGG Special Feature. Tuexenia 37: 375-378.

Dengler, J., Becker, T., Conradi, T., Dolnik, T., Heindl-Tenhunen, B., Jensen, K., Kaufmann, J., Klotz, M., Kurzböck, C., (...) \& Schuhmacher, O. 2017. GrassVeg.DE - die neue kollaborative Vegetationsdatenbank für alle Offenlandhabitate Deutschlands. Tuexenia 37: 447-455.

Gilhaus, K., Boch, S., Fischer, M., Hölzel, N., Kleinebecker, T., Prati, D., Rupprecht, D., Schmitt, B. \& Klaus, V.H. 2017. Grassland management in Germany: effects on plant diversity and vegetation composition. Tuexenia 37: 379-397.

Kelemen, A., Tölgyesi, C., Kun, R., Molnár, Z., Vadász, C. \& Tóth, K. 2017. Positive small-scale effects of shrubs on diversity and flowering in pastures. Tuexenia 37: 399-413.

Szabó, G., Zimmermann, Z., Catorci, A., Csontos, P., Wichmann, B., Szentes, S., Barczi, A. \& Penksza, K. 2017. Comparative study on grasslands dominated by Festuca vaginata and F. pseudovaginata in the Carpathian Basin. Tuexenia 37: 415-429.

Balázs Deák, Debrecen, Hungary, debalazs@gmail.com Thomas Becker, Trier, Germany, beckerth@uni-trier.de



Calcareous sandy grassland in Hungary. Photo: Balázs Deák. 


\section{Towards a consistent classification of European grasslands- Virtual Special Feature}

In spring 2017, the Virtual Special Feature (VSF) "Towards a consistent classification of European grasslands" (eds. J. Dengler, E. Bergmeier, W. Willner and M. Chytrý) was completed, comprising a total of eight contributions from 20132017. This VSF was a joint initiative of the two IAVS Working Groups EDGG and EVS (European Vegetation Survey).

In 2013 Applied Vegetation Science invited vegetation scientists to work towards developing a consistent international classification of European grasslands, and to publish results of these studies in the journal (Dengler et al. 2013). Seven original research articles were published between 2013 and 2017 and subsequently collected in this Virtual Special Issue. It includes studies from South-Western Europe (Rodríguez-Rojo et al. 2014; García-Madrid et al. 2016; Gavilán et al. 2017), the Balkan Peninsula (Eliáš et al. 2013; Šilc et al. 2014) and the forest-steppe and steppe zones of Central and Eastern Europe (Willner et al. 2017). One study synthesizes data across Europe (Jiménez-Alfaro et al. 2014). The studied vegetation includes Mediterranean and continental dry grasslands, mesic and wet meadows and pastures, saline grasslands, alpine grasslands and fens. The papers also represent the current spectrum of analytical tools used for plot-based vegetation classification, including various methods of both unsupervised and supervised classification and a range of approaches to parameterize vegetation types obtained from the classification. New methodological approaches were tested for the first time in some of these papers (Rodríguez Rojo et al. 2014; Willner et al. 2017).

Towards a consistent classification of European grasslands Jürgen Dengler, Erwin Bergmeier, Wolfgang Willner and Milan Chytrý

Diversity and classification of tall humid herb grasslands (Molinio-Holoschoenion) in Western Mediterranean Europe

Ana S. García-Madrid, Maria Pilar Rodríguez-Rojo, Paloma Cantó and José A. Molina

A review of high-mountain acidophilous vegetation in the Iberian Peninsula

Rosario G. Gavilán, Beatriz Vilches, Xavier Font and Borja Jiménez-Alfaro

Vegetation diversity of mesic grasslands (Arrhenatheretalia) in the Iberian Peninsula

Maria Pilar Rodríguez-Rojo, Federico Fernández-González, Lubomír Tichý and Milan Chytrý

Grassland vegetation of the Molinio-Arrhenatheretea class in the NW Balkan Peninsula

Urban Šilc, Svetlana Aćić, Željko Škvorc, Daniel Krstonošić, Jozo Franjić and Zora Dajić Stevanović

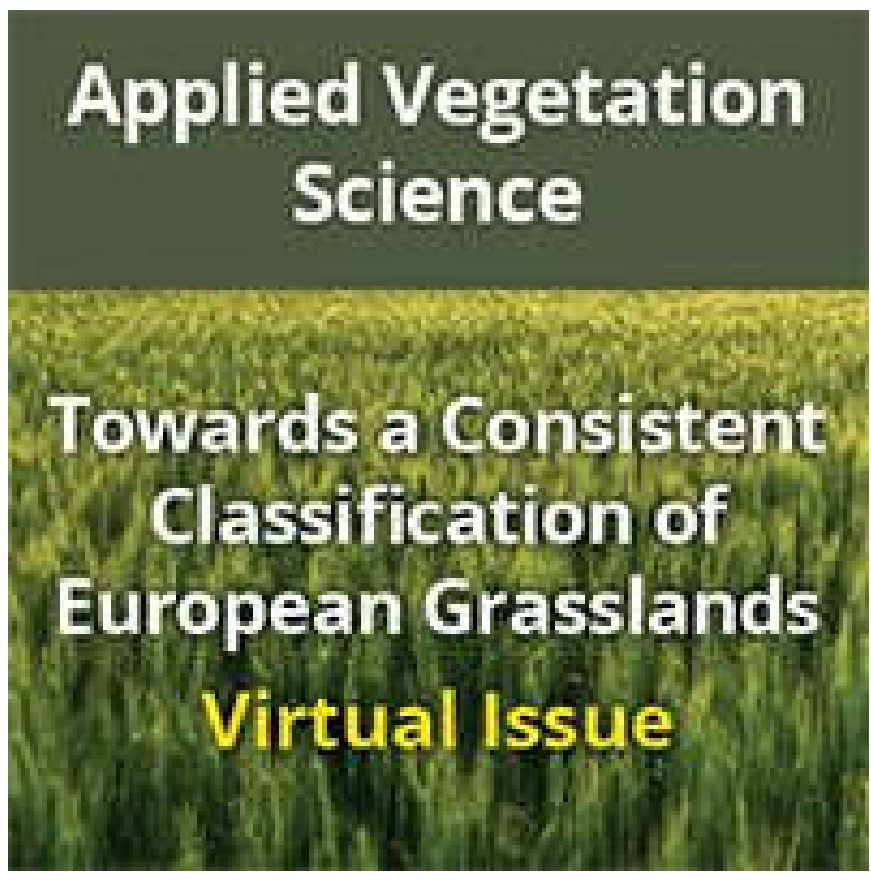

Vegetation diversity of salt-rich grasslands in Southeast

Europe

Pavol Eliáš Jr, Desislava Sopotlieva, Daniel Dítě, Petra Hájková, Iva Apostolova, Dušan Senko, Zuzana Melečková and Michal Hájek

A higher-level classification of the Pannonian and western Pontic steppe grasslands (Central and Eastern Europe) Wolfgang Willner, Anna Kuzemko, Jürgen Dengler, Milan Chytrý, Norbert Bauer, Thomas Becker, Claudia BiţăNicolae, Zoltán Botta-Dukát, Andraž Čarni, János Csiky, Ruzica Igić, Zygmunt Kącki, Iryna Korotchenko, Matthias Kropf, Mirjana Krstivojević-Ćuk, Daniel Krstonošić, Tamás Rédei, Eszter Ruprecht, Luise Schratt-Ehrendorfer, Yuri Semenishchenkov, Zvjezdana Stančić, Yulia Vashenyak, Denys Vynokurov and Monika Janišová

Biogeographic patterns of base-rich fen vegetation across Europe

Borja Jiménez-Alfaro, Michal Hájek, Rasmus Ejrnaes, John Rodwell, Paweł Pawlikowski, Eddy J. Weeda, Jarmo Laitinen, Absjørn Moen, Ariel Bergamini, Liene Aunina, Lucia Sekulová, Teemu Tahvanainen, François Gillet, Ute Jandt, Daniel Dítě, Petra Hájková, Gilles Corriol, Hanna Kondelin and Tomás E. Díaz

Jürgen Dengler, Wädenswil, Switzerland,

juergen.dengler@zhaw.ch 


\section{Recent publications of our members}

In this section, the contents of which will also be made available via our homepage, we want to facilitate an overview of grassland-related publications throughout Eurasia and to improve their accessibility. You are invited to send lists of such papers from the last three years following the format below to anyameadow.ak@gmail.com and didem.ambarli@gmail.com. We will include your e-mail address so that readers can request a pdf. For authors who own full copyright, we can also post a pdf on the EDGG homepage.

\section{Biodiversity}

Fantinato, E., Del Vecchio, S., Slaviero, A., Conti, L., Acosta, A.T.R. \& Buffa, G. 2016. Does flowering synchrony contribute to the sustainment of dry grassland biodiversity? Flora: Morphology, Distribution, Functional Ecology of Plants 222: 96-103.

Godó, L., Valkó, O., Tóthmérész, B., Török, P., Kelemen, A. \& Deák, B. 2017. Scale-dependent effects of grazing on the species richness of alkaline and sand grasslands. Tuexenia 37: 229-246.

Kelemen, A., Tölgyesi, C., Kun, R., Molnár, Z., Vadász, C. \& Tóth, K. 2017. Positive small-scale effects of shrubs on diversity and flowering in pastures. Tuexenia 37: 399413.

\section{Ecology}

Fantinato, E., Del Vecchio, S., Baltieri, M., Fabris, B. \& Buffa, G. 2017. Are food-deceptive orchid species really functionally specialized for pollinators? Ecological Research 32: 1-9.

Fantinato, E., Del Vecchio, S., Giovanetti, M., Acosta, A.T.R. \& Buffa, G. 2017. New insights into plants coexistence in species-rich communities: the pollination interaction perspective. Journal of Vegetation Science. doi: 10.1111/jvs.12592.

Sonkoly, J., Valkó, O., Deák, B., Miglécz, T., Tóth, K., Radócz, Sz., Kelemen, A., Riba, M., Vasas, G., Tóthmérész, B. \& Török P. 2017. A new aspect of grassland vegetation dynamics: cyanobacterium colonies affect establishment success of plants. Journal of Vegetation Science 28: 475-483.

Kreyling, J., Dengler, J., Walter, J., Velev, N., Uğurlu, E., Sopotlieva, D., Ransijn, J., Picon-Cochard, C., Nijs, I., (...) \& Jentsch, A. 2017. Species richness effects on grassland recovery from drought depend on community productivity in a multisite experiment. Ecology Letters 20: 1405-1413.

Valkó, O., Kelemen, A., Miglécz, T., Török, P., Deák, B., Tóth, K., Tóth, J.P. \& Tóthmérész, B. 2017. Litter removal does not compensate detrimental fire effects on biodiversity in regularly burned semi-natural grasslands. Science of the Total Environment. doi:10.1016/ j.scitotenv.2017.11.356.

\section{Management and restoration}

Török, K., Csecserits, A., Somodi, I., Kövendi-Jakó, A., Halász, K., Rédei, T. \& Halassy, M. 2017. Restoration prioritization for industrial area applying multiple potential natural vegetation modeling. Restoration Ecology. doi:10.1111/rec.12584.

Kelemen, A., Tóthmérész, B., Valkó, O., Miglécz, T., Deák, B. \& Török, P. 2017. New aspects of grassland recovery in old-fields revealed by trait-based analyses of perennial-crop-mediated succession. Ecology and Evolution 7: 2432-2440.

Török, P., Kelemen, A.,Valkó, O., Miglécz, T., Tóth, K., Tóth, E., Sonkoly, J., Kiss, R., Csecserits, A., (...) \& Tóthmérész, B. 2017. Succession in soil seed banks and its implications for restoration of calcareous sand grasslands. Restoration Ecology. doi: 10.1111/rec.12611.

Valkó, O., Deák, B., Török, P., Kelemen, A., Miglécz, T. \& Tóthmérész, B. 2017. Filling up the gaps - Passive restoration does work on linear landscape scars. Ecological Engineering 102: 501-508.

\section{Population biology of grassland species}

Fantinato, E., Giovanetti, M., Del Vecchio, S. \& Buffa, G. 2016. Altitudinal patterns of floral morphologies in dry calcareous grasslands. Plant Sociology 53: 83-90.

Sonkoly, J., Deák, B., Valkó, O., Molnár, V.A., Tóthmérész, B. \& Török, P. Do rare herbs have large seeds? Seed size - distribution range trade-off hypothesis. Ecology and Evolution. doi: 10.1002/ece3.3568.

\section{Contact to the authors:}

Péter Török, molinia@gmail.com

Anikó Csecserits, csecserits.aniko@okologia.mta.hu

\section{Edy Fantinato, edy.fantinato@unive.it}

Jürgen Dengler, juergen.dengler@uni-bayreuth.de 


\section{Forthcoming events}

\section{Macroecology 2018-Macroecology in the age of big data}

10-13 April 2018, Birmensdorf, Switzerland

The meeting webpage: https://www.wsl.ch/lud/macro2018/ Abstract deadline: 18 December 2017.

\section{$27^{\text {th }}$ European Vegetation Survey Meeting}

23-26 May 2018, Wrocław, Poland

The meeting will be hosted by the University of Wrocław (Zygmunt Kącki and colleagues).

The meeting webpage: http://evs2018wroclaw.uni.wroc.pl/

\section{5th Eurasian Grassland Conference}

4-8 June 2018, Sulmona, Italy

More information in this Bulletin at the pages 5-8.

\section{ECE 2018-XI European Congress of Entomology}

2-6 July 2018, Naples, Italy

The congress webpage: http://www.ece2018.com/

\section{1th EDGG Field Workshop}

6-13 July 2018, Eastern Alps, Austria

More information in this Bulletin at the pages 9-10.

$61^{\text {th }}$ Symposium of the International Association for Vegetation Science (IAVS)

23-27 July 2018, Bozeman (Montana), U.S.A.

The symposium webpage is not yet available.

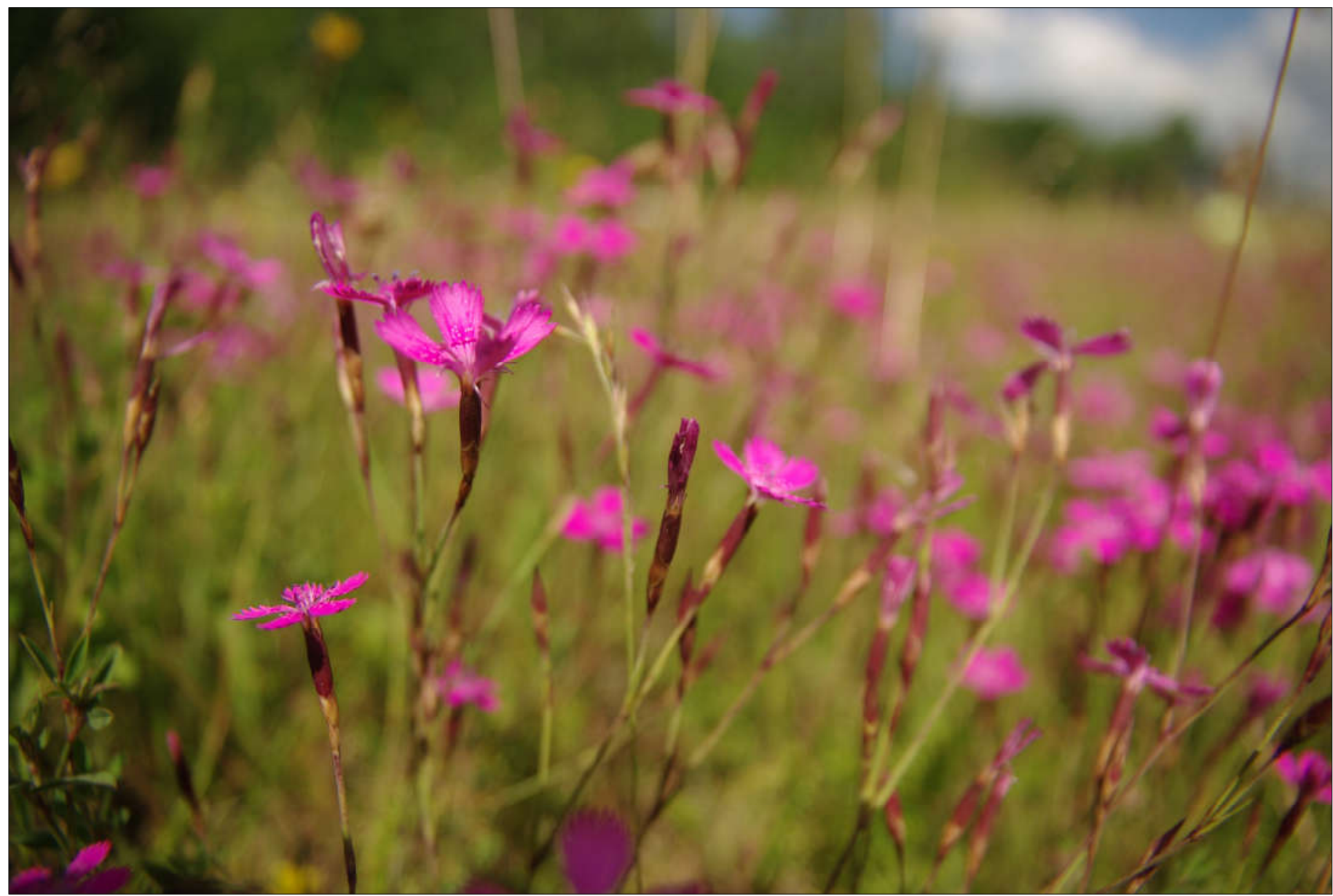

Dianthus deltoides at Latvian grasslands. Photo: Valentina Borodulina. 
EDGG

Gpass|खnd]

research and conservation

The Bulletin is published quarterly from the Biocentre Klein Flottbek, University of Hamburg, c/o Jürgen Dengler, Ohnhorststr. 18, 22609 Hamburg, Germany. It is sent to all members of the group (1259 members from 67 countries as of $15^{\text {th }}$ December 2017) and together with all previous issues, it is also freely available at http://www.edgg.org/publications.htm. Bulletin 35 (2017) of the EDGG was published on 15 December 2017.

Editors-in-Chief: Anna Kuzemko (Uman', Ukraine, anyameadow.ak@gmail.com), Idoia Biurrun (Bilbao, Spain, idoia.biurrun@ehu.eus)

Members of the Editorial Board : Laura Sutcliffe (Göttingen, Germany), Didem Ambarlı (Düzce, Turkey), Jürgen Dengler (Wädenswil, Switzerland), Péter Török (Debrecen, Hungary), Stephen Venn (Helsinki, Finland), Michael Vrahnakis (Karditsa, Greece).

The copyright of the included texts, photographs, and other figures remains with their authors. If you wish to re-use them or parts of them, please, obtain the written consent of the authors first.

Important dates: The deadline for Bulletin 36 is 10 January 2018

Bulletin 36 to appear: Winter 2018

EDGG on the web: http://www.edgg.org

EDGG in Facebook: https://www.facebook.com/groups/938367279561202

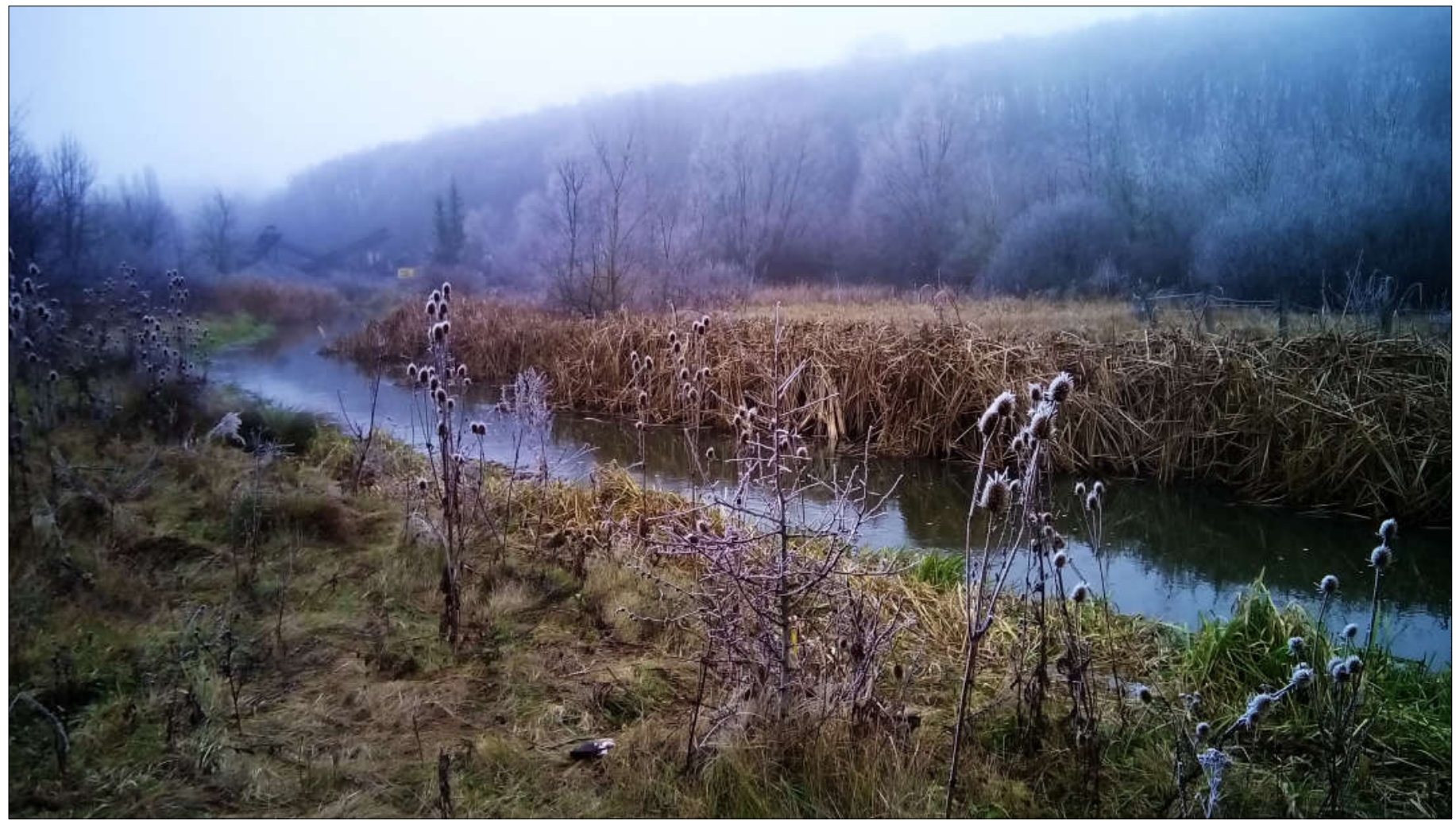

Anthropogenic grasslands in Umanka River valley near Pykivets village, Uman district, Cherkasy region, Ukraine. Photo: A. Kuzemko. 